Radionuclides, Inorganic Constituents,

Organic Compounds, and Bacteria in

Water from Selected Wells and Springs

from the Southern Boundary of the Idaho

National Engineering Laboratory to the

Hagerman Area, Idaho, 1992

By ROY C. BARTHOLOMAY AND DANIEL D. EDWARDS, U.S. GEOLOGICAL SURVEY and LINFORD J. CAMPBELL, IDAHO DEPARTMENT OF WATER RESOURCES

U.S. GEOLOGICAL SURVEY

Open-File Report 94-76

Prepared in cooperation with the

U.S. DEPARTMENT OF ENERGY

and

IDAHO DEPARTMENT OF WATER RESOURCES

Idaho Falls, Idaho

1994

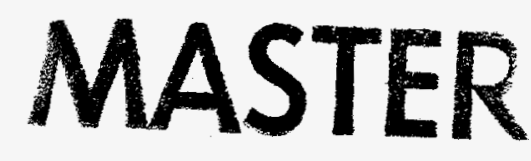




\section{U.S. DEPARTMENT OF THE INTERIOR \\ BRUCE BABBITT, Secretary}

U.S. GEOLOGICAL SURVEY

Robert M. Hirsch, Acting Director

For additional information write to:

U.S. Geological Survey

INEL, MS 4148

P.O. Box 2230

Idaho Falls, ID 83403
Copies of this report can be purchased from:

U.S. Geological Survey

Earth Science Information Center

Open-File Reports Section

Box 25286, MS 517

Denver Federal Center

Denver, CO 80225 


\section{DISCLAIMER}

This report was prepared as an account of work sponsored by an agency of the United States Government. Neither the United States Government nor any agency thereof, nor any of their employees, make any warranty, express or implied, or assumes any legal liability or responsibility for the accuracy, completeness, or usefuiness of any information, apparatus, product, or process disclosed, or represents that its use would not infringe privately owned rights. Reference herein to any specific commercial product, process, or service by trade name, trademark, manufacturer, or otherwise does not necessarily constitute or imply its endorsement, recommendation, or favoring by the United States Government or any agency thereof. The views and opinions of authors expressed herein do not necessarily state or reflect those of the United States Government or any agency thereof. 


\section{DISCLAIMER}

Portions of this document may be illegible in electronic image products. Images are produced from the best available original document. 


\section{CONTENTS}

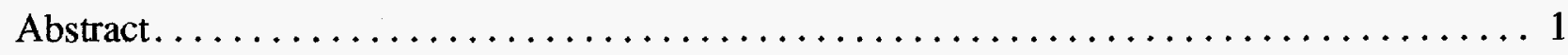

Introduction $\ldots \ldots \ldots \ldots \ldots \ldots \ldots \ldots \ldots \ldots \ldots \ldots \ldots \ldots \ldots \ldots \ldots \ldots \ldots$

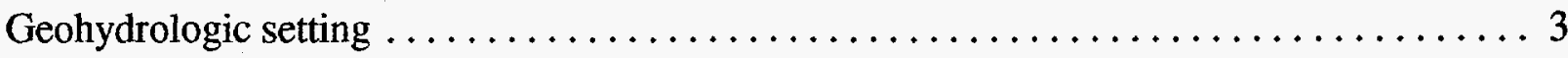

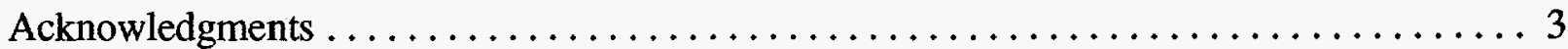

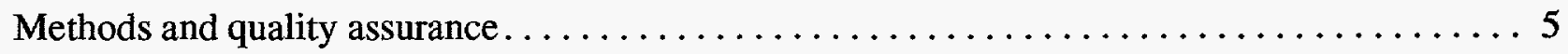

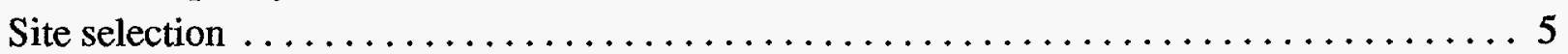

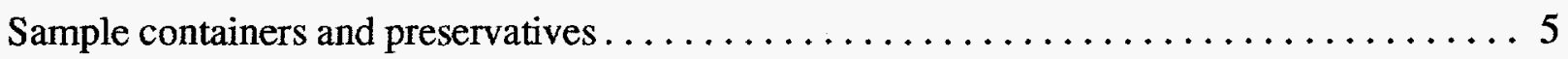

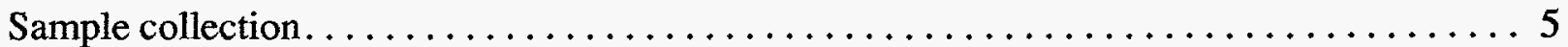

Quality assurance ............................... 8

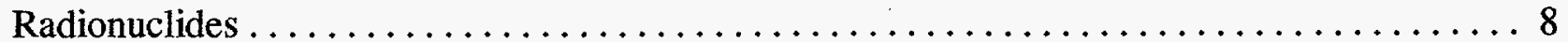

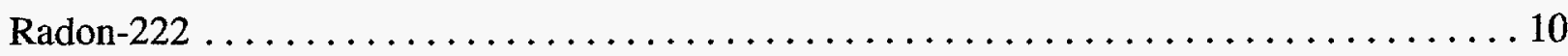

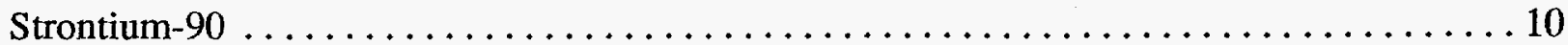

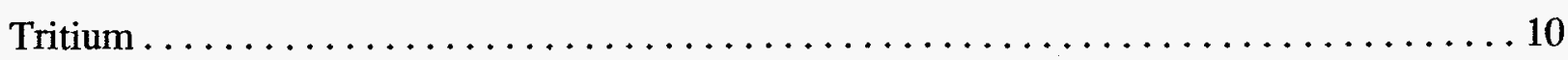

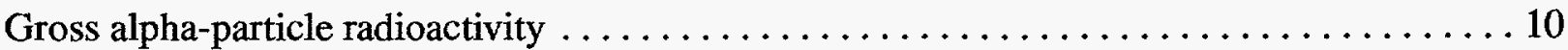

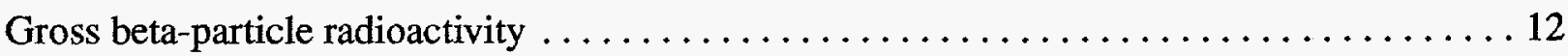

Total uranium . . . . . . . . . . . . . . . . . . . . . . . . . . . 12

Radium. . . . . . . . . . . . . . . . . . . . . . . . . . . . . 12

Cesium-137, radium-226, uranium-235, uranium-238, and potassium-40 $\ldots \ldots \ldots \ldots$

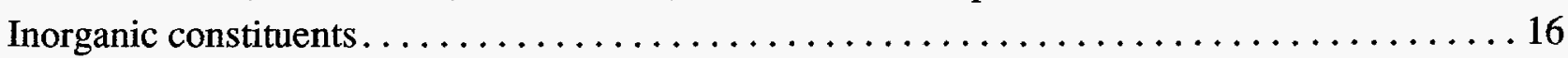

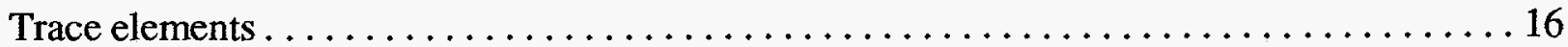

Common ions. . . . . . . . . . . . . . . . . . . . . . . . . . . . 26

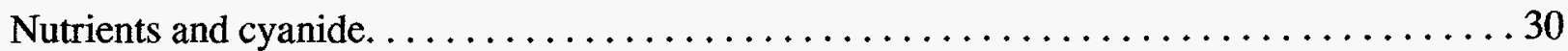

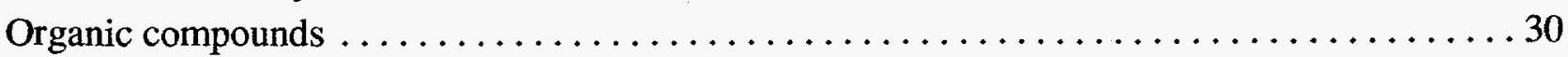

Dissolved organic carbon. . . . . . . . . . . . . . . . . . . . . 30

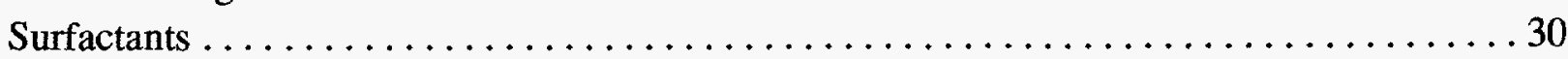

Purgeable organic compounds . . . . . . . . . . . . . . . . . . . . . 30

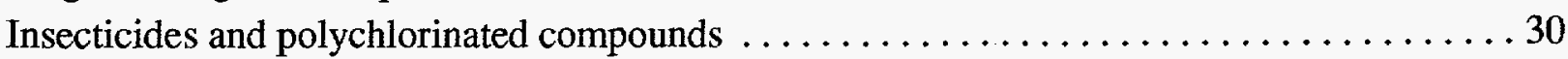

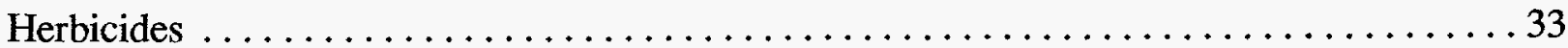

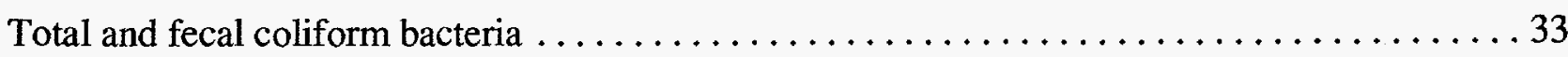

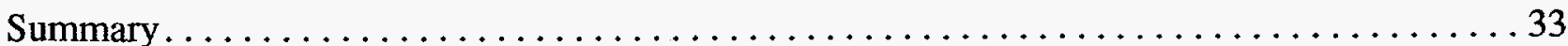

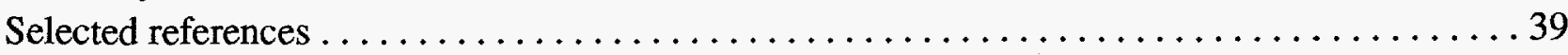

\section{ILLUSTRATIONS}

Figure 1. Map showing location of the study area between the Idaho National Engineering Laboratory and Hagerman, Idaho.

2. Map showing location of selected water-quality sampling sites on the eastern Snake

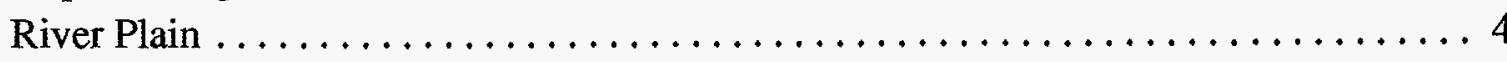




\section{TABLES}

Table 1. Containers and preservatives used for water-sample collection. . . . . . . . . . . 6

2. Results of field measurements of water for $\mathrm{pH}$, specific conductance, temperature, alkalinity, and concentrations of dissolved oxygen from selected wells and springs, eastern Snake River Plain . . . . . . . . . . . . . . . . . . . . . . 7

3. Maximum contaminant levels for types of radioactivity and selected radionuclides in drinking water $\ldots \ldots \ldots \ldots \ldots \ldots \ldots \ldots \ldots \ldots \ldots \ldots \ldots \ldots \ldots$

4. Concentrations of radon-222, strontium-90, and tritium in water from selected wells and springs, eastern Snake River Plain . . . . . . . . . . . . . . . . 11

5. Concentrations of gross alpha-particle radioactivity in water from selected wells and springs, eastern Snake River Plain . . . . . . . . . . . . . . . . 13

6. Concentrations of gross beta-particle radioactivity in water from selected wells and springs, eastern Snake River Plain . . . . . . . . . . . . . . . . 14

7. Dissolved concentrations of total uranium and selected radium isotopes in water from selected wells and springs, eastern Snake River Plain . . . . . . . . . 15

8. Concentrations of cesium-137, radium-226, uranium-235, uranium-238, and potassium-40 in water from selected wells and springs, eastern Snake River Plain. . . . 17

9. Maximum contaminant levels and reporting levels of selected trace elements in

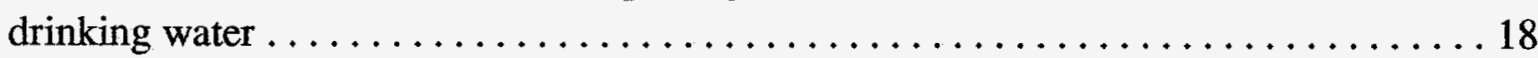

10. Concentrations of dissolved trace elements and hexavalent and total chromium in water from selected wells and springs, eastern Snake River Plain. . . . . . . . . . . . . 19

11. Maximum contaminant levels and reporting levels of selected common ions in drinking water. . . . . . . . . . . . . . . . . . . . . . . 27

12. Concentrations of dissolved common ions in water from selected wells and springs, eastern Snake River Plain

13. Concentrations of total common ions in water from selected wells and springs, eastern Snake River Plain.

14. Maximum contaminant levels and reporting levels of selected nutrients, cyanide, dissolved organic carbon, and surfactants in drinking water $\ldots \ldots \ldots \ldots \ldots \ldots \ldots$

15. Concentrations of nutrients, cyanide, dissolved organic carbon, and surfactants in water from selected wells and springs, eastern Snake River Plain. . . . . . . . . 32

16. Maximum contaminant levels and reporting levels of selected purgeable organic

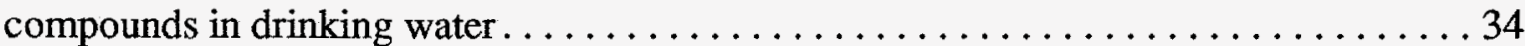

17. Maximum contaminant levels and reporting levels of selected insecticides and gross polychlorinated compounds in drinking water. . . . . . . . . . . . . 35

18. Maximum contaminant levels and reporting levels of triazines and chlorophenoxy-

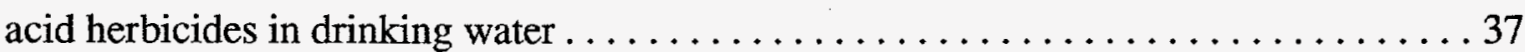

19. Presence of total and fecal coliform bacteria in water from selected wells and

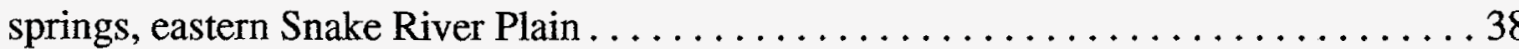




\section{CONVERSION FACTORS AND ABBREVIATED WATER-QUALITY UNITS}

\begin{tabular}{rcl}
\multicolumn{1}{c}{ Multiply } & \multicolumn{1}{c}{ By } & \multicolumn{1}{c}{ To Obtain } \\
\hline acre-foot per year (acre-ft/yr) & 1,233 & cubic meter per year \\
foot $(\mathrm{ft})$ & 0.3048 & meter \\
gallon (gal) & 3.785 & liter \\
mile (mi) & 1.609 & kilometer \\
millirem per year (mrem/yr) & 0.010 & millisievert per year \\
picocurie per liter $(\mathrm{pCi} / \mathrm{L})$ & 0.037 & becquerel per liter \\
square mile $\left(\mathrm{mi}{ }^{2}\right)$ & 2.590 & square kilometer \\
\hline
\end{tabular}

Temperature can be converted from degrees Celsius $\left({ }^{\circ} \mathrm{C}\right)$ to degrees Fahrenheit $\left({ }^{\circ} \mathrm{F}\right)$ by the equation: ${ }^{\circ} \mathrm{F}=\left({ }^{\circ} \mathrm{C} \times 1.8\right)+32$

Abbreviated water-quality units used in report: gram $(\mathrm{g})$; milliliter $(\mathrm{mL})$; liter $(\mathrm{L})$; microgram per liter $(\mu \mathrm{g} / \mathrm{L})$; milligram per liter $(\mathrm{mg} / \mathrm{L})$; micrometer $(\mu \mathrm{m})$; and microsiemens per centimeter at 25 degrees Celsius $(\mu \mathrm{S} / \mathrm{cm})$. 


\title{
Radionuclides, Inorganic Constituents, Organic Compounds, and Bacteria in Water from Selected Wells and Springs from the Southern Boundary of the Idaho National Engineering Laboratory to the Hagerman Area, Idaho, 1992
}

\author{
By Roy C. Bartholomay and Daniel D. Edwards, U.S. Geological Survey \\ and Linford J. Campbell, Idaho Department of Water Resources
}

\begin{abstract}
The U.S. Geological Survey and the Idaho Department of Water Resources, in response to a request from the U.S. Department of Energy, sampled 18 sites as part of a long-term project to monitor water quality of the Snake River Plain aquifer from the southern boundary of the Idaho National Engineering Laboratory to the Hagerman area. Water samples were collected and analyzed for selected radionuclides, inorganic constituents, organic compounds, and bacteria. The samples were collected from 13 irrigation wells, 1 domestic well, 1 spring, 2 stock wells, and 1 public supply well. Quality assurance samples also were collected and analyzed.
\end{abstract}

None of the samples analyzed for radionuclides, inorganic constituents, or organic compounds exceeded the established maximum contaminant levels for drinking water. Most of the radionuclide and inorganic constituent concentrations exceeded their respective reporting levels. Most of the samples analyzed for surfactants and dissolved organic carbon had concentrations that exceeded their reporting levels. None of the samples contained reportable concentrations of purgeable organic compounds or pesticides. Total coliform bacteria was present in nine samples.

\section{INTRODUCTION}

Recently, the public has expressed much concern about waste disposal practices at the Idaho National Engineering Laboratory (INEL) and the impact these practices might have had on the water quality of the Snake River Plain aquifer. The U.S. Department of Energy (DOE) requested that the U.S. Geological Survey (USGS) conduct two studies to respond to the public's concern and to gain a greater understanding of the chemical quality of water in the aquifer. The first study described a one-time sampling effort during May 1989 in the eastern part of the A \& B Irrigation District in Minidoka County (Mann and Knobel, 1990). The second study, an ongoing annual sampling effort in the area between the southern boundary of the INEL and Hagerman (fig. 1), is being conducted in cooperation with the Idaho Department of Water Resources and the DOE. The initial round of sampling for the second study involved analyzing water samples collected from 55 sites during August and September 1989 (Wegner and Campbell, 1991). Water samples from 19 of the initial 55 sites were collected and analyzed during 1990 (Bartholomay and others, 1992). Eighteen more of the initial 55 sites were sampled during 1991 (Bartholomay and others, 1993). This report summarizes the analyses of water samples collected in June-September 1992 from the remaining 18 sites.

The INEL includes about $890 \mathrm{mi}^{2}$ of the northeastern part of the eastern Snake River Plain and is about $110 \mathrm{mi}$ northeast of the Hagerman area (fig. 1). Wastewater containing chemical and 


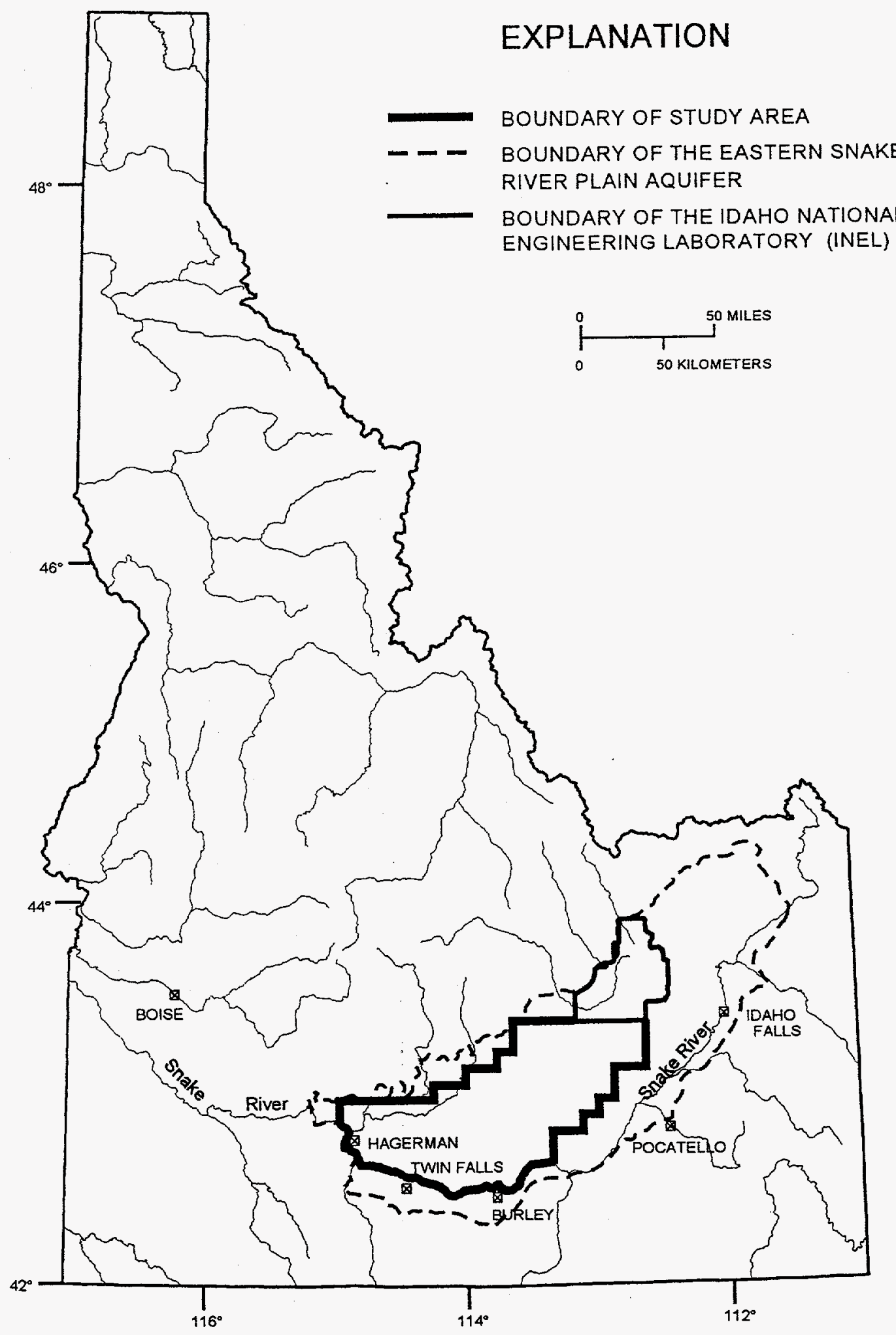

Figure 1. - Location of the study area between the Idaho National Engineering Laboratory and Hagerman, Idaho. 
radiochemical wastes generated at the INEL was discharged mostly to ponds and wells in the past. Since 1983, most aqueous wastes have been discharged to infiltration ponds. Many of the constituents in the wastewater enter the aquifer indirectly following percolation through the unsaturated zone (Pittman and others, 1988).

Chemical and radioactive wastes have migrated from less than 1 to about 9 mi southwest of the disposal areas at the INEL (Pittman and others, 1988). Between 1983 and 1985, tritium was detected at concentrations of less than the reporting level to $3,400 \pm 200 \mathrm{pCi} / \mathrm{L}$ in water from three wells along the southern boundary of the INEL. Since April 1986, tritium concentrations in water from wells near the southem boundary of the INEL have been less than the Radiological and Environmental Sciences Laboratory analytical method detection limit of $500 \mathrm{pCi} / \mathrm{L}$ (Mann and Cecil, 1990).

Water samples from 18 sites (fig. 2) were analyzed for selected radionuclides, trace elements, common ions, nutrients, cyanide, dissolved organic carbon (DOC), surfactants, purgeable organic compounds, carbamate and organophosphorus insecticides, organochlorine insecticides, gross polychlorinated biphenyls (PCB's), gross polychlorinated naphthalenes (PCN's), and triazine and chlorophenoxy-acid herbicides, by the USGS National Water Quality Laboratory (NWQL) at Arvada, Colo. The same sites also were sampled for analyses of selected radionuclides, trace elements, common ions, and total and fecal coliform bacteria by the Idaho State University (ISU) Environmental Monitoring Laboratory at Pocatello, Idaho, and the Idaho Department of Health and Welfare Laboratory (IDHWL) at Twin Falls and Boise, Idaho. Two replicate water samples and three equipment blanks also were collected and analyzed as a measure of quality assurance.

\section{Geohydrologic Setting}

The eastern Snake River Plain is a northeasttrending structural basin about $200 \mathrm{mi}$ long and 50 to $70 \mathrm{mi}$ wide. The basin, bounded by faults on the northwest and downwarping and faulting on the southeast, has been filled with basaltic lava flows interbedded with terrestrial sediments (Whitehead, 1986). Individual basalt flows average 20 to $25 \mathrm{ft}$ in thickness with an aggregate thickness of several thousand feet in places. Alluvial fan deposits are composed primarily of sand and gravel, whereas in areas where streams were dammed by basalt flows, the sediments are predominantly silt and clay (Garabedian, 1986). Rhyolitic lava flows and tuffs are exposed locally at the surface and may exist at depth under most of the eastern plain. A 10,365 -ft-deep test hole at the INEL penetrated about $2,160 \mathrm{ft}$ of basalt and sediment and $8,205 \mathrm{ft}$ of tuffaceous and rhyolitic volcanic rocks (Mann, 1986).

Movement of water in the aquifer generally is from the northeast to the southwest. Water moves horizontally through basalt interflow zones and vertically through joints and interfingering edges of the interflow zones. Infiltration of surface water, heavy pumpage, geologic conditions, and seasonal fluxes in recharge and discharge locally affect the movement of ground water (Garabedian, 1986).

The Snake River Plain aquifer is recharged by seepage from the upper reaches of the Snake River, tributaries and canals, infiltration from irrigation and precipitation, and underflow from tributary valleys on the perimeter of the plain. Discharge from the aquifer primarily is by pumpage for irrigation and spring flow to the Snake River (Mann and Knobel, 1990). Between 1902 and 1980, spring flow to the Snake River increased about 1.2 million acre-ft/yr, largely as a result of increased recharge from infiltration of irrigation water (Mann, 1989, p. 5).

\section{Acknowledgments}

The authors gratefully acknowledge the well owners for granting permission to collect the water samples and extend special thanks to Dale Connell of the Shoshone District of the Bureau of Land Management for his help in locating and pumping two of the wells for sample collection. The authors are grateful for technical review of the manuscript by L. Flint Hall of the Idaho Department of Health and Welfare and Linda $M$. Williams of the USGS. 


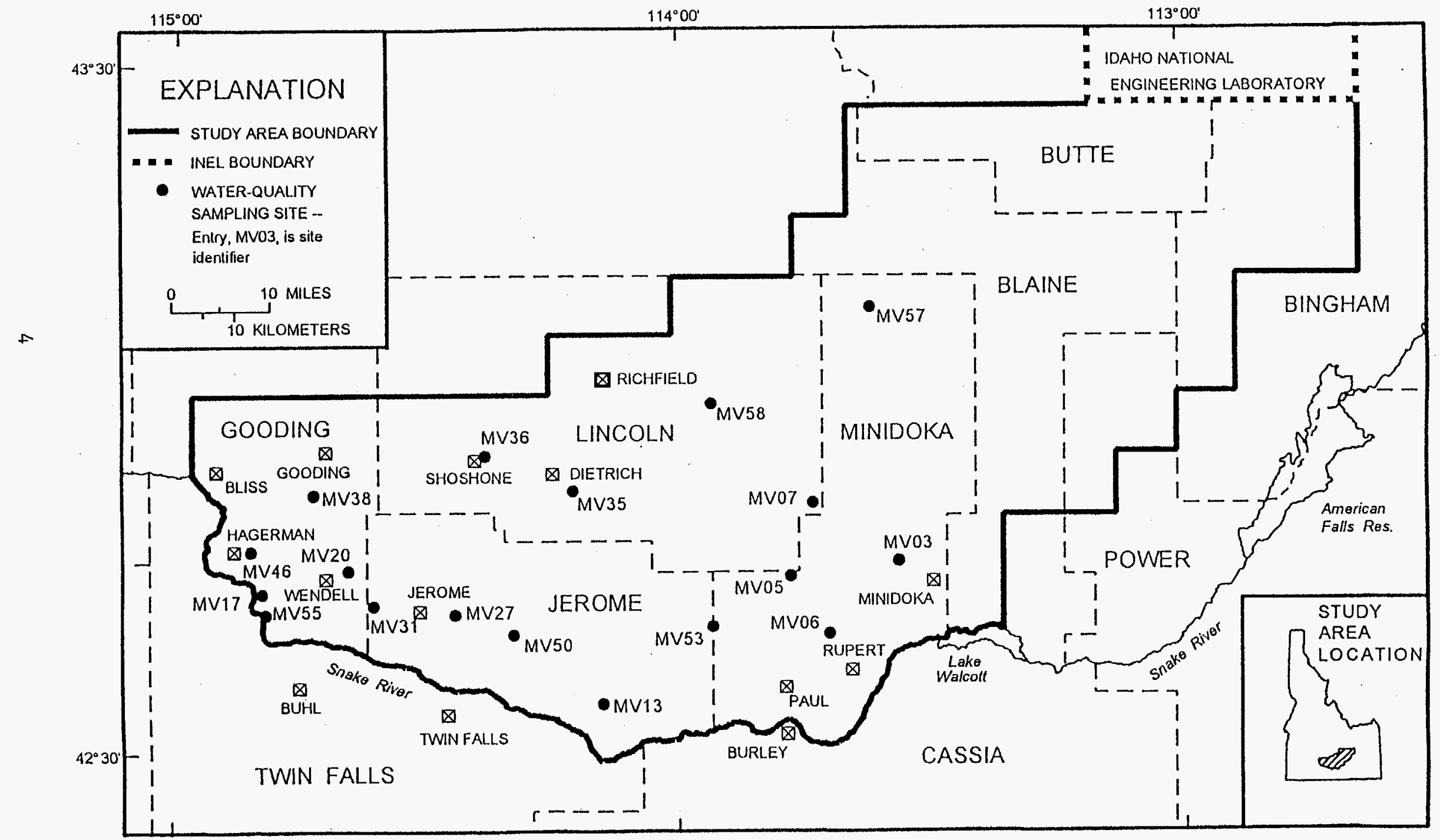

Figure 2. -- Location of selected water-quality sampling sites on the eastern Snake River Plain. 


\section{METHODS AND QUALITY ASSURANCE}

The methods used in sampling for selected chemicals generally followed the guidelines established by the USGS (Goerlitz and Brown, 1972; Stevens and others, 1975; Wood, 1981; Claassen, 1982; W.L. Bradford, USGS, written commun., 1985; Wershaw and others, 1987; and Fishman and Friedman, 1989). The methods used in the field and quality assurance practices are outlined in following sections.

\section{Site Selection}

Water samples were collected at 18 locations (fig. 2), including 13 irrigation wells, 1 domestic well, 1 spring, 2 stock wells, and 1 public supply well. Two replicate water samples and one equipment blank also were collected. The irrigation wells and public supply well were equipped with turbine pumps. The domestic and stock wells were equipped with submersible pumps. Criteria for site selection were geographic location, ease of sample collection, and long-term access.

\section{Sample Containers and Preservatives}

Sample containers and preservatives differ depending on the constituent(s) for which analyses are requested. Samples analyzed by the NWQL were collected and preserved in accordance with laboratory requirements specified by Pritt and Jones (1989). Water samples analyzed by ISU were collected in accordance with laboratory requirements specified by the director of the Environmental Monitoring Program at ISU. Water samples analyzed by the IDHWL were collected and preserved in accordance with laboratory requirements specified by the director of the Bureau of Laboratories at the IDHWL. Containers and preservatives were supplied by the respective laboratories. Containers and preservatives used for this study are listed on table 1.

\section{Sample Collection}

Two of the irrigation wells discharged into stilling ponds and were sampled near the discharge pipe. The remaining irrigation wells were sampled from spigots in discharge lines near pumps; the domestic, stock, and public supply wells were sampled from spigots closest to pumps. All the wells either were pumping on arrival of the sampling team or were started on arrival and, when possible, pumped long enough to ensure that pressure tanks and pumping systems had been thoroughly flushed as evidenced by stable $\mathrm{pH}$, specific conductance, and temperature measurements. The spring was sampled near the USGS gaging station by collecting a grab sample from an area of moving water.

Chemical and physical characteristics monitored at the water-sampling sites included $\mathrm{pH}$, specific conductance, water temperature, alkalinity, and concentrations of dissolved oxygen. These characteristics were monitored during pumping using methods described by Wood (1981) and Hardy and others (1989). A water sample was collected when measurements of these properties indicated probable hydraulic and chemical stability. After collection, sample containers were sealed with laboratory film, labeled, and packed into ice chests for shipment by overnight-delivery mail to the NWQL. The samples collected for the IDHWL and ISU were stored in coolers until they were hand-delivered to the respective laboratories.

Measurements of $\mathrm{pH}$, specific conductance, water temperature, alkalinity, and concentrations of dissolved oxygen are shown on table 2 .

Measured $\mathrm{pH}$ of water from sampling sites ranged from 7.6 to 8.4, which is within the U.S. Environmental Protection Agency's (1989) recommended range of 6.5 to 8.5 for community water systems. Specific conductance measurements ranged from 242 to $800 \mu \mathrm{S} / \mathrm{cm}$. Measurements of water temperature ranged from 12.0 to $17.0^{\circ} \mathrm{C}$. The Idaho Department of Health and Welfare (IDHW, 1989) has established a secondary maximum contaminant level of $26.6^{\circ} \mathrm{C}$ for temperature. Alkalinity as calcium carbonate ranged from 106 to $226 \mathrm{mg} / \mathrm{L}$. Concentrations of dissolved oxygen ranged from 6.8 to $10.0 \mathrm{mg} / \mathrm{L}$.

Conditions at the sampling site during sample collection were recorded in a field logbook; a chain-of-custody record was used to track the samples from the time of collection until delivery 
Table 1.-Containers and preservatives used for water-sample collection

[Abbreviations: gal, gallon; g, gram; $\mathrm{L}$, liter; $\mathrm{mL}$, milliliter; $\mu \mathrm{m}$, micrometer; ${ }^{\circ} \mathrm{C}$, degrees Celsius; $\mathrm{HgCl}_{2}$, mercuric chloride; $\mathrm{NaCl}$, sodium chloride; $\mathrm{HNO}_{3}$, nitric acid; $\mathrm{K}_{2} \mathrm{Cr}_{2} \mathrm{O}_{7}$, potassium dichromate; $\mathrm{NaOH}$, sodium hydroxide. Chilled samples were shipped by overnight-delivery mail. Analyzing laboratory: NWQL, U.S. Geological Survey National Water Quality Laboratory; IDHWL, Idaho Department of Health and Welfare Laboratory; ISU, Idaho State University Environmental Monitoring Laboratory]

\begin{tabular}{|c|c|c|c|c|c|c|}
\hline \multirow[b]{2}{*}{ Type of constituent } & \multicolumn{2}{|l|}{ Container } & \multicolumn{2}{|l|}{ Preservative } & \multirow[b]{2}{*}{ Other treatment } & \multirow{2}{*}{$\begin{array}{c}\text { Laboratory } \\
\text { providing analyses }\end{array}$} \\
\hline & Type & Size & Type & Size & & \\
\hline Pesticides & Glass, baked & $1 \mathrm{~L}$ & None & None & Chill $4^{\circ} \mathrm{C}$ & NWQL \\
\hline Nutrients & Polyethylene, brown & $125 \mathrm{~mL}$ & $\mathrm{HgCl}_{2} / \mathrm{NaCl}$ & $0.5 \mathrm{~mL}$ & $0.45 \mu \mathrm{m}$ filter, chill $4^{\circ} \mathrm{C}$ & NWQL \\
\hline \multirow[t]{2}{*}{ Purgeable organic compounds } & Glass, baked & $40 \mathrm{~mL}$ & None & None & Chill $4^{\circ} \mathrm{C}$ & NWQL \\
\hline & Glass, baked & $40 \mathrm{~mL}$ & Ascorbic acid & $.05 \mathrm{~g}$ & Chill $4^{\circ} \mathrm{C}$ & IDHWL \\
\hline \multirow[t]{2}{*}{ Trace elements } & Polyethylene, acid rinsed & $500 \mathrm{~mL}$ & $\mathrm{HNO}_{3}$ & $2 \mathrm{~mL}$ & $0.45 \mu \mathrm{m}$ filter & NWQL \\
\hline & Polyethylene, acid rinsed & $1 \mathrm{~L}$ & $\mathrm{HNO}_{3}$ & $5 \mathrm{~mL}$ & $0.45 \mu \mathrm{m}$ filter & IDHWL \\
\hline Mercury & Glass, acid rinsed & $250 \mathrm{~mL}$ & $\mathrm{~K}_{2} \mathrm{Cr}_{2} \mathrm{O}_{7} / \mathrm{HNO}_{3}$ & $10 \mathrm{~mL}$ & $0.45 \mu \mathrm{m}$ filter & NWQL \\
\hline \multirow[t]{2}{*}{ Tritium } & Glass, baked & $1 \mathrm{~L}$ & None & None & None & NWQL \\
\hline & Polyethylene & $500 \mathrm{~mL}$ & None & None & None & ISU \\
\hline Radium & Polyethylene, acid rinsed & $1 \mathrm{~L}$ & $\mathrm{HNO}_{3}$ & $4 \mathrm{~mL}$ & $0.45 \mu \mathrm{m}$ filter & NWQL \\
\hline Radon-222 & Glass vials & $20 \mathrm{~mL}$ & Scintillation cocktail & $10 \mathrm{~mL}$ & None & NWQL \\
\hline \multirow[t]{2}{*}{ Strontium-90 } & Polyethylene, acid rinsed & $1 \mathrm{~L}$ & $\mathrm{HNO}_{3}$ & $4 \mathrm{~mL}$ & $0.45 \mu \mathrm{m}$ filter & NWQL \\
\hline & Polyethylene & 1 gal & None & None & None & ISU \\
\hline Uranium & Polyethylene, acid rinsed & $1 \mathrm{~L}$ & $\mathrm{HNO}_{3}$ & $4 \mathrm{~mL}$ & $0.45 \mu \mathrm{m}$ filter & NWQL \\
\hline \multirow[t]{2}{*}{ Other radionuclides } & Polyethylene, acid rinsed & $1 \mathrm{~L}$ & None & None & None & NWQL \\
\hline & Polyethylene & $1 \mathrm{gal}$ & None & None & None & ISU \\
\hline Bacteria & Polyethylene, autoclaved & $250 \mathrm{~mL}$ & None & None & Chill $4^{\circ} \mathrm{C}$ & IDHWL \\
\hline Dissolved organic carbon & Glass, baked & $125 \mathrm{~mL}$ & None & None & Silver filter, chill $4^{\circ} \mathrm{C}$ & NWQL \\
\hline Surfactants & Polyethylene & $250 \mathrm{~mL}$ & None & None & Chill $4^{\circ} \mathrm{C}$ & NWQL \\
\hline Cyanide & Polyethylene & $250 \mathrm{~mL}$ & $\mathrm{NaOH}$ & $5 \mathrm{ml}$ & Chill $4^{\circ} \mathrm{C}$ & NWQL \\
\hline \multirow[t]{5}{*}{ Common ions } & Polyethylene, acid rinsed & $500 \mathrm{~mL}$ & $\mathrm{HNO}_{3}$ & $2 \mathrm{~mL}$ & $0.45 \mu \mathrm{m}$ filter & NWQL \\
\hline & Polyethylene, acid rinsed & $500 \mathrm{~mL}$ & $\mathrm{HNO}_{3}$ & $2 \mathrm{~mL}$ & None & NWQL \\
\hline & Polyethylene & $250 \mathrm{~mL}$ & None & None & $0.45 \mu \mathrm{m}$ filter & NWQL \\
\hline & Polyethylene & $250 \mathrm{~mL}$ & None & None & None & NWQL \\
\hline & Polyethylene, acid rinsed & $1 \mathrm{~L}$ & None & None & Chill $4^{\circ} \mathrm{C}$ & IDHWL \\
\hline
\end{tabular}


Table 2.-Results of field measurements of water for $\mathrm{pH}$, specific conductance, temperature, alkalinity, and concentrations of dissolved oxygen from selected wells and springs, eastern Snake River Plain

[See figure 2 for location of sites. Site use: I, irrigation; Sp, spring; P, public supply; QA, quality assurance (MV-44 is a replicate of MV-46; MV-60 is a replicate of MV-36; MV-62C is an equipment blank); D, domestic; S, stock. Date sampled: month/day/year. Units: $\mathrm{pH}$, negative base-10 logarithm of hydrogen ion activity, in moles per liter; specific conductance, microsiemens per centimeter at $25^{\circ} \mathrm{C}$ (degrees Celsius); temperature, ${ }^{\circ} \mathrm{C}$; alkalinity, $\mathrm{mg} / \mathrm{L}$ as calcium carbonate using digital titration with 0.16 normal sulfuric acid; dissolved oxygen, $\mathrm{mg} / \mathrm{L}$ using Azide modification of Winkler method (American Public Health Association and Water Pollution Control Federation, 1985). Symbol: --, no analysis was performed]

\begin{tabular}{|c|c|c|c|c|c|c|c|}
\hline $\begin{array}{c}\text { Site } \\
\text { identifier }\end{array}$ & Site use & $\begin{array}{c}\text { Date } \\
\text { sampled }\end{array}$ & $\mathrm{pH}$ & $\begin{array}{c}\text { Specific } \\
\text { conductance }\end{array}$ & Temperature & Alkalinity & $\begin{array}{c}\text { Dissolved } \\
\text { oxygen }\end{array}$ \\
\hline MV-03 & $\mathbf{I}$ & $7 / 28 / 92$ & 7.9 & 418 & 13.5 & 137 & 8.5 \\
\hline MV-05 & I & $7 / 30 / 92$ & 7.9 & 644 & 13.0 & 174 & 8.5 \\
\hline MV-06 & $\mathbf{I}$ & $7 / 28 / 92$ & 7.6 & 620 & 15.0 & 226 & 6.8 \\
\hline MV-07 & I & $7 / 30 / 92$ & 8.1 & 348 & 14.0 & 130 & 8.0 \\
\hline MV-13 & I & $6 / 23 / 92$ & 7.9 & 600 & 16.0 & 192 & 7.5 \\
\hline MV-17 & $\mathrm{Sp}$ & $7 / 27 / 92$ & 8.2 & 412 & 15.0 & 140 & 8.6 \\
\hline MV-20 & I & $7 / 27 / 92$ & 7.8 & 410 & 15.5 & 157 & 8.3 \\
\hline MV-27 & I & $7 / 27 / 92$ & 7.9 & 671 & 15.0 & 183 & 8.2 \\
\hline MV-31 & I & $6 / 23 / 92$ & 7.9 & 613 & 15.0 & 168 & 8.1 \\
\hline MV-35 & $\mathbf{I}$ & $6 / 24 / 92$ & 8.2 & 282 & 15.0 & 114 & 7.8 \\
\hline MV-36 & $\mathbf{P}$ & $7 / 29 / 92$ & 7.8 & 449 & 14.0 & 205 & 8.4 \\
\hline MV-38 & I & $7 / 29 / 92$ & 7.9 & 366 & 15.0 & 160 & 8.1 \\
\hline MV-44 & QA & $6 / 23 / 92$ & 8.2 & 307 & 16.0 & 124 & 6.8 \\
\hline MV-46 & I & $6 / 23 / 92$ & 8.2 & 307 & 16.0 & 124 & 6.8 \\
\hline MV-50 & I & $9 / 15 / 92$ & 7.8 & 715 & 14.5 & 193 & 8.1 \\
\hline MV-53 & $\mathrm{D}$ & $7 / 28 / 92$ & 7.8 & 800 & 17.0 & 222 & 7.6 \\
\hline MV-55 & I & $7 / 30 / 92$ & 7.9 & 415 & 15.0 & 144 & 8.6 \\
\hline MV-57 & $S$ & $6 / 30 / 92$ & 8.4 & 242 & 12.5 & 106 & 8.7 \\
\hline MV-58 & $S$ & $6 / 30 / 92$ & 8.4 & 275 & 12.0 & 126 & 10.0 \\
\hline MV-60 & QA & $7 / 29 / 92$ & 7.8 & 449 & 14.0 & 205 & 8.4 \\
\hline MV-62C & $\mathrm{QA}$ & $11 / 12 / 92$ & 9.5 & 11 & 24.5 & - & - \\
\hline
\end{tabular}


to the analyzing laboratory. These records are available for inspection at the USGS Project Office at the INEL.

\section{Quality Assurance}

Detailed descriptions of internal quality control and overall quality assurance practices used by the NWQL are provided in reports by Friedman and Erdmann (1982) and Jones (1987). Water samples analyzed by the NWQL were collected in accordance with a quality assurance plan for quality of water activities conducted by personnel at the INEL Project Office; the plan was finalized in June 1989, and revised in March 1992, and is available for inspection at the USGS Project Office at the INEL. The water samples analyzed by the IDHWL were collected in accordance with procedures described by $W$. Baker, J. Dodds, and B. Ellis (IDHW, written commun., 1991). Water samples analyzed by ISU were collected in accordance with procedures described by B. Graham (ISU, written commun., 1991). Ten percent of the water samples were quality assurance replicate samples. Sample MV-44 is a replicate of sample MV-46. Sample MV-60 is a replicate of sample MV-36. Samples MV-62A and MV-62B are a pair of equipment blanks collected on June 24, 1992 and July 30, 1992, respectively, and analyzed for purgeable organic compounds and selected dissolved trace elements by the IDHWL. Sample MV-62C is an equipment blank collected on November 12, 1992 and analyzed for dissolved organic carbon by the NWQL. Because the equipment blank water samples are not representative of wells and springs sampled for this report, they will not be included in the discussions of the various constituents measured but will be included in some of the tables.

\section{RADIONUCLIDES}

Water samples were analyzed for radon-222, strontium-90, tritium, gross alpha- and gross betaparticle radioactivity, total uranium, radium-226, and radium-228. In addition, gamma-emitting radionuclides were identified. The samples were analyzed using methods described by Thatcher and others (1977) and U.S. Environmental
Protection Agency (1987). Maximum contaminant levels for the types of radioactivity and for selected radionuclides are listed on table 3.

An analytical uncertainty, $\mathbf{s}$, is calculated for each radionuclide concentration. This report presents the analytical uncertainty as 2 s. Guidelines for interpreting analytical results are based on an extension of the method described by Currie (1984). In radiochemical analyses, laboratory measurements are made on a target sample and a prepared blank. Instrument signals for the sample and blank vary randomly. Therefore, it is essential to distinguish between two key aspects of the problem of detection: (1) The instrument signal for the sample must be greater than the signal for the blank to make the decision that there was detection; and (2) an estimation must be made of the minimum concentration that will yield a sufficiently large signal to make the correct decision for detection or nondetection most of the time. The first aspect of the problem is a qualitative decision based on signals and a definite criterion for detection. The second aspect of the problem is an estimation of the detection capabilities of a complete measurement process that includes hypothesis testing.

In the laboratory, instrument signals must exceed a critical level to make the qualitative decision whether the radionuclide or radioactivity was detected. Concentrations that equal $1.6 \mathrm{~s}$ meet this criterion; at 1.6s, there is about a 95-percent probability that the correct decision-not detected-will be made. Given a large number of samples, as many as 5 percent of the samples with measured concentrations greater than or equal to $1.6 \mathrm{~s}$, which were concluded as being detected, might not contain the radioactive constituent. These measurements are referred to as false positives and are errors of the first kind in hypothesis testing.

Once the critical level of $1.6 \mathrm{~s}$ has been defined, the minimum detectable concentration can be established. Concentrations that equal $3 \mathbf{s}$ represent a measurement at the minimum detectable concentration. For true concentrations of $3 \mathrm{~s}$ or greater, there is a 95-percent-or-more probability of correctly concluding that the radioactive constituent was detected in a sample. 
Table 3.-Maximum contaminant levels for types of radioactivity and selected radionuclides in drinking water

[The maximum contaminant levels were established pursuant to the recommendations of the U.S. Environmental Protection Agency (1989, p. 550) for community water systems and are for comparison purposes only. The proposed maximum contaminant levels-in parentheses-are from U.S. Environmental Protection Agency (1991a). The maximum contaminant level given for gross alpha-particle radioactivity includes radium-226 but excludes radon and uranium. The maximum contaminant level given for gross beta-particle radioactivity and photon radioactivity excludes radioactivity from natural sources and is included for comparison purposes only. Maximum contaminant levels given for strontium- 90 and tritium are average annual concentrations assumed to produce a total body or organ dose of $4 \mathrm{mrem} / \mathrm{yr}$ (millirem per year) of betaparticle radiation. Abbreviations: $\mathrm{pCi} / \mathrm{L}$, picocurie per liter; $\mu \mathrm{g} / \mathrm{L}$, microgram per liter]

\begin{tabular}{lc}
\hline \multicolumn{1}{c}{ Type of radioactivity or radionuclide } & Maximum contaminant level \\
\hline Gross alpha-particle radioactivity & $15 \mathrm{pCi} / \mathrm{L}$ \\
Gross beta-particle and gamma radioactivity & $4 \mathrm{mrem} / \mathrm{yr}$ \\
Radium-226 plus radium-228 & $5 \mathrm{pCi} / \mathrm{L}$ \\
Radium-226 & $(20 \mathrm{pCi} / \mathrm{L})$ \\
Radium-228 & $(20 \mathrm{pCi} / \mathrm{L})$ \\
Radon-222 & $(300 \mathrm{pCi} / \mathrm{L})$ \\
Strontium-90 & $8 \mathrm{pCi} / \mathrm{L}$ \\
Total uranium & $(20 \mu \mathrm{g} / \mathrm{L})$ \\
Tritium & $20,000 \mathrm{pCi} / \mathrm{L}$ \\
\hline
\end{tabular}


Given a large number of samples, as many as 5 percent of the samples with measured concentrations greater than or equal to $3 \mathbf{s}$, which were concluded as being not detected, could contain the radioactive constituent at the minimum detectable concentration. These measurements are referred to as false negatives and are errors of the second kind in hypothesis testing.

True radionuclide concentrations between $1.6 \mathrm{~s}$ and $3 \mathrm{~s}$ have larger errors of the second kind. That is, there is a greater-than-5-percent probability of false negative results for samples with true concentrations between $1.6 \mathrm{~s}$ and $3 \mathrm{~s}$, and although the radionuclide or radioactivity might have been detected, such detection may not be considered reliable; at $1.6 \mathrm{~s}$, the probability of a false negative is about 50 percent.

These guidelines are based on counting statistics alone and do not include systematic or random errors inherent in laboratory procedures. The values $1.6 \mathrm{~s}$ and $3 \mathrm{~s}$ vary slightly with background or blank counts and with the number of gross counts for individual analyses. The use of the critical level and minimum detectable concentration aids the reader in the interpretation of analytical results and does not represent absolute concentrations of radioactivity that may or may not have been detected. In this report, if the concentration of a selected radionuclide was equal to or greater than $3 \mathrm{~s}$, the concentration is considered to be above a "reporting level." The reporting level should not be confused with the analytical method detection limit, which is based on laboratory procedures. At small concentrations, the reporting level approaches the analytical method detection limit; however, at larger concentrations, they may be significantly different.

\section{Radon-222}

Radon-222 is a naturally occurring radioactive gas that results from the decay of radium- 226 . Concentrations of radon-222 in 19 of the water samples analyzed by the NWQL exceeded the reporting level and ranged from $49 \pm 30$ to $297 \pm 32 \mathrm{pCi} / \mathrm{L}$ (table 4 ). Concentrations in all the samples were less than the proposed maximum contaminant level of $300 \mathrm{pCi} / \mathrm{L}$ (table 3).

\section{Strontium-90}

Strontium-90 is a fission product that was widely distributed in the environment during atmospheric weapons tests. Strontium-90 generally is present in ground water as a result of these tests and from nuclear industry wastedisposal practices. All water samples analyzed by the NWQL contained concentrations of dissolved strontium-90 less than the reporting level (table 4). All the samples analyzed by ISU contained concentrations of total strontium-90 less than the reporting level.

\section{Tritium}

Tritium, a radioactive isotope of hydrogen, is formed in nature by interactions of cosmic rays with gases in the upper atmosphere. Tritium also is produced in thermonuclear detonations and is a waste product of the nuclear power industry. Samples were submitted to the ISU laboratory and the NWQL for analysis. The ISU laboratory used a liquid scintillation technique and the NWQL used an enrichment and gas counting technique. The analytical method detection limit for the laboratories differed. The analytical method detection limit for the ISU laboratory was $300 \mathrm{pCi} / \mathrm{L}$ using a 200 -minute counting period and that for the NWQL was $0.3 \mathrm{pCi} / \mathrm{L}$ using a 360- to 1,200-minute counting period.

The concentrations of tritium in the water samples are shown on table 4. Concentrations in 18 of the water samples analyzed by the NWQL exceeded the reporting level and ranged from $1.00 \pm 0.58$ to $70.4 \pm 4.48 \mathrm{pCi} / \mathrm{L}$. Concentrations in all water samples analyzed by the ISU laboratory were less than the reporting level. For the purpose of comparison, background concentrations of tritium in ground water in Idaho generally range from 75 to $150 \mathrm{pCi} / \mathrm{L}$ (Orr and others, 1991). The maximum contaminant level for tritium in public drinking-water supplies is 20,000 pCi/L (table 3).

\section{Gross Alpha-Particle Radioactivity}

Gross alpha-particle radioactivity is a measure of the total radioactivity given off as alpha particles during the radioactive decay process; however, laboratories normally report the 
Table 4.-Concentrations of radon-222, strontium-90, and tritium in water from selected wells and springs, eastern Snake River Plain

[See figure 2 for location of sites. Analyses were performed by the U.S. Geological Survey National Water Quality Laboratory (NWQL) and Idaho State University (ISU) Environmental Monitoring Laboratory using the following methods: radon-222 by liquid scintillation; strontium- 90 by chemical separation and precipitation; tritium by enrichment and gas counting at the NWQL and by liquid scintillation at ISU. Analytical results and uncertainties-for example $175 \pm 31$ - in picocuries per liter $(\mathrm{pCi} / \mathrm{L})$. Analytical uncertainties are reported as $2 \mathrm{s.} \mathrm{Symbol:} \mathrm{*,}$ quality assurance sample (MV-44 is a replicate of MV-46; MV-60 is a replicate of MV-36)]

\begin{tabular}{|c|c|c|c|c|c|}
\hline Site identifier & $\begin{array}{c}\text { Radon-222 } \\
\text { NWQL }\end{array}$ & $\begin{array}{c}\text { Strontium-90, } \\
\text { dissolved } \\
\text { NWQL }\end{array}$ & $\begin{array}{c}\text { Strontium-90, } \\
\text { total } \\
\text { ISU }\end{array}$ & $\begin{array}{l}\text { Tritium } \\
\text { NWQL }\end{array}$ & $\begin{array}{c}\text { Tritium } \\
\text { ISU }\end{array}$ \\
\hline MV-03 & $175 \pm 31$ & $0.032 \pm 0.213$ & $-0.6 \pm 1.2$ & $1.00 \pm 0.58$ & $20 \pm 200$ \\
\hline MV-05 & $197 \pm 50$ & $.115 \pm 0.241$ & $-1.4 \pm 1.0$ & $10.2 \pm 0.77$ & $-70 \pm 200$ \\
\hline MV-06 & $149 \pm 30$ & $-.025 \pm 0.178$ & $-.1 \pm 1.0$ & $70.4 \pm 4.48$ & $130 \pm 200$ \\
\hline MV-07 & $162 \pm 62$ & $.008 \pm 0.205$ & $.15 \pm 0.80$ & $.58 \pm 0.58$ & $70 \pm 200$ \\
\hline MV-13 & $114 \pm 25$ & $.034 \pm 0.165$ & $-1.5 \pm 1.0$ & $69.4 \pm 5.12$ & $90 \pm 200$ \\
\hline MV-17 & $126 \pm 35$ & $.162 \pm 0.245$ & $-4.1 \pm 1.0$ & $9.60 \pm 0.70$ & $0 \pm 200$ \\
\hline MV-20 & $107 \pm 23$ & $.021 \pm 0.213$ & $.1 \pm 1.0$ & $20.1 \pm 1.34$ & $40 \pm 200$ \\
\hline MV-27 & $138 \pm 33$ & $.127 \pm 0.216$ & $.2 \pm 1.0$ & $44.8 \pm 3.20$ & $260 \pm 200$ \\
\hline MV-31 & $62 \pm 24$ & $.070 \pm 0.168$ & $-3.8 \pm 1.0$ & $33.9 \pm 2.56$ & $180 \pm 200$ \\
\hline MV-35 & $106 \pm 23$ & $.072 \pm 0.176$ & $.05 \pm 0.94$ & $3.17 \pm 0.58$ & $150 \pm 200$ \\
\hline MV-36 & $236 \pm 40$ & $-.001 \pm 0.207$ & $.4 \pm 0.8$ & $58.2 \pm 3.84$ & $-40 \pm 200$ \\
\hline MV-38 & $215 \pm 38$ & $.077 \pm 0.142$ & $.2 \pm 0.4$ & $49.3 \pm 3.20$ & $-170 \pm 200$ \\
\hline MV-44* & $134 \pm 33$ & $.052 \pm 0.204$ & $-3.9 \pm 1.0$ & $10.3 \pm 0.77$ & $0 \pm 200$ \\
\hline MV-46 & $137 \pm 33$ & $-.007 \pm 0.145$ & $-2.3 \pm 1.4$ & $11.8 \pm 1.02$ & $260 \pm 200$ \\
\hline MV-50 & $297 \pm 32$ & $.185 \pm 0.241$ & $0 \pm 1.2$ & $64.0 \pm 5.12$ & $20 \pm 200$ \\
\hline MV-53 & $163 \pm 54$ & $-.022 \pm 0.199$ & $-.5 \pm 0.8$ & $65.3 \pm 4.48$ & $0+200$ \\
\hline MV-55 & $194 \pm 50$ & $.142 \pm 0.221$ & $.14 \pm 0.68$ & $9.50 \pm 0.64$ & $-170 \pm 200$ \\
\hline MV-57 & $32 \pm 29$ & $.055 \pm 0.177$ & $-.9 \pm 1.0$ & $-.19 \pm 0.58$ & $110+200$ \\
\hline MV-58 & $49 \pm 30$ & $.094 \pm 0.177$ & $-7.0 \pm 2.0$ & $46.4 \pm 3.20$ & $-90 \pm 200$ \\
\hline$M V-60^{*}$ & $268 \pm 43$ & $.136 \pm 0.270$ & $-.4 \pm 1.6$ & $60.2 \pm 3.84$ & $60 \pm 200$ \\
\hline
\end{tabular}


radioactivity as if it were all given off by one radionuclide. In this report, concentrations are reported both as natural uranium in micrograms per liter and as thorium-230 in picocuries per liter by the NWQL, and as americium-241 in picocuries per liter by the ISU laboratory.

The gross alpha-particle radioactivity in the dissolved fraction of all the water samples analyzed by the NWQL exceeded the reporting level (table 5). The concentrations reported as uranium ranged from $1.40 \pm 0.707$ to

$4.48 \pm 1.26 \mu \mathrm{g} / \mathrm{L}$. The concentrations reported as thorium-230 ranged from $0.970 \pm 0.490$ to $3.09 \pm 0.865 \mathrm{pCi} / \mathrm{L}$. Gross alpha-particle radioactivity in the suspended fraction of all the water samples analyzed by the NWQL was less than the reporting level. Gross alpha-particle radioactivity reported as total americium- 241 in all the water samples analyzed by ISU was less than the reporting level. Total concentrations of dissolved and suspended fractions of gross alphaparticle radioactivity in all the water samples were less than the maximum contaminant level of $15 \mathrm{pCi} / \mathrm{L}$ (table 3 ).

\section{Gross Beta-Particle Radioactivity}

Gross beta-particle radioactivity is a measure of the total radioactivity given off as beta particles during the radioactive decay process. The laboratory instruments for these measurements are calibrated to a single radionuclide, cesium-137, or a chemically similar pair of radionuclides in equilibrium, strontium-90 in equilibrium with yttrium-90. In this report, concentrations are reported as cesium-137 in picocuries per liter, and as strontium-90 in equilibrium with yttrium-90 in picocuries per liter. Reporting of the concentrations of gross beta-particle radioactivity in either one of these ways is for reference purposes only and does not imply that the radioactivity is attributed to these specific isotopes. The average annual concentrations of strontium- 90 and cesium137 in public drinking-water supplies that produce a 4 -mrem/yr dose are $8 \mathrm{pCi} / \mathrm{L}$ and $120 \mathrm{pCi} / \mathrm{L}$, respectively. Gross beta-particle radioactivity measurements should not be compared directly to these concentrations.
Gross beta-particle radioactivity was measured in both the dissolved and suspended fractions of the water samples analyzed by the NWQL. Concentrations of dissolved gross beta-particle radioactivity reported as cesium- 137 and as strontium-90 in equilibrium with yttrium-90 in all of the water samples analyzed by the NWQL exceeded the reporting levels (table 6); concentrations ranged from $2.79 \pm 0.959$ to $9.94 \pm 2.06 \mathrm{pCi} / \mathrm{L}$, and from $2.09 \pm 0.652$ to $7.38 \pm 1.53 \mathrm{pCi} / \mathrm{L}$, respectively. Gross beta-particle radioactivity in the suspended fraction of all the water samples analyzed by the NWQL was less than the reporting level. Total concentrations of gross beta-particle radioactivity reported as cesium-137 in nine of the water samples analyzed by ISU equaled or exceeded the reporting levels (table 6); concentrations ranged from $6 \pm 4$ to $9 \pm 4 \mathrm{pCi} / \mathrm{L}$.

\section{Total Uranium}

Uranium is a widely distributed element that has three naturally occurring radioactive isotopes: uranium-238, uranium-235, and uranium-234. These isotopes undergo a complex series of radioactive decay that results in their ultimate conversion to stable isotopes of lead (Haglund, 1972). Total uranium is a measurement of the combined concentrations of these three isotopes. Dissolved total uranium concentrations in all water samples analyzed by the NWQL exceeded the reporting levels (table 7); concentrations ranged from $1.08 \pm 0.162$ to $3.30 \pm 0.495 \mu \mathrm{g} / \mathrm{L}$. The proposed maximum contaminant level for total uranium is $20 \mu \mathrm{g} / \mathrm{L}$ (table 3 ).

\section{Radium}

Radium-224 and radium-228 are naturally occurring radioactive decay products of thorium232; radium-226 is a naturally occurring decay product of uranium-238. Radium-224 was not detected in any of the water samples. Concentrations of dissolved radium-226 in 18 of the water samples analyzed by the NWQL exceeded the reporting level; concentrations ranged from $0.022 \pm 0.008$ to $0.061 \pm 0.013 \mathrm{pCi} / \mathrm{L}$ (table 7 ). Concentrations of dissolved radium-228 in 5 water samples analyzed by the NWQL exceeded the reporting level (table 7); concentrations ranged from $0.042 \pm 0.013$ to $1.62 \pm 0.590 \mathrm{pCi} / \mathrm{L}$. 
Table 5.-Concentrations of gross alpha-particle radioactivity in water from selected wells and springs, eastern Snake River Plain

[See figure 2 for location of sites. Analyses were performed by the U.S. Geological Survey National Water Quality Laboratory (NWQL) and the Idaho State University (ISU) Environmental Monitoring Laboratory using a residue procedure. Analytical results and uncertainties-for example $274 \pm 1.05$ - in indicated units. Analytical uncertainties are reported as $2 \mathrm{~s}$.

Abbreviations: $\mu \mathrm{g} / \mathrm{L}$, microgram per liter; $\mathrm{pCi} / \mathrm{L}$, picocurie per liter. Symbol: *, quality assurance sample (MV-44 is a replicate of MV-46; MV-60 is a replicate of MV-36)]

\begin{tabular}{lccccc}
\hline Site identifier & $\begin{array}{c}\text { Dissolved as } \\
\text { uranium } \\
\text { NWQL }(\mu \mathrm{g} / \mathrm{L})\end{array}$ & $\begin{array}{c}\text { Dissolved as } \\
\text { thorium-230 } \\
\text { NWQL }(\mathrm{pCi} / \mathrm{L})\end{array}$ & $\begin{array}{c}\text { Suspended as } \\
\text { uranium } \\
\text { NWQL }(\mu \mathrm{g} / \mathrm{L})\end{array}$ & $\begin{array}{c}\text { Suspended as } \\
\text { thorium-230 } \\
\text { NWQL }(\mathrm{pCi} / \mathrm{L})\end{array}$ & $\begin{array}{c}\text { Total as } \\
\text { americium-241 } \\
\text { ISU (pCi/L) }\end{array}$ \\
\hline MV-03 & $2.74 \pm 1.05$ & $2.00 \pm 0.764$ & $-0.193 \pm 0.352$ & $-0.110 \pm 0.206$ & $0 \pm 2$ \\
MV-05 & $3.04 \pm 1.10$ & $2.22 \pm 0.804$ & $-.230 \pm 0.280$ & $-.130 \pm 0.165$ & $0 \pm 2$ \\
MV-06 & $2.39 \pm 0.921$ & $1.67 \pm 0.648$ & $.075 \pm 0.310$ & $.042 \pm 0.174$ & $0 \pm 2$ \\
MV-07 & $2.15 \pm 0.893$ & $1.51 \pm 0.630$ & $.129 \pm 0.285$ & $.072 \pm 0.162$ & $0 \pm 2$ \\
MV-13 & $3.13 \pm 1.05$ & $2.15 \pm 0.719$ & $-.232 \pm 0.283$ & $-.129 \pm 0.164$ & $0 \pm 2$ \\
MV-17 & $1.89 \pm 0.872$ & $1.31 \pm 0.609$ & $-.091 \pm 0.354$ & $-.050 \pm 0.195$ & $0 \pm 2$ \\
MV-20 & $3.07 \pm 1.13$ & $1.92 \pm 0.739$ & $-.337 \pm 0.319$ & $-.196 \pm 0.199$ & $0 \pm 2$ \\
MV-27 & $3.78 \pm 1.18$ & $2.62 \pm 0.823$ & $-.339 \pm 0.320$ & $-.195 \pm 0.198$ & $-1 \pm 2$ \\
MV-31 & $3.26 \pm 1.08$ & $2.31 \pm 0.770$ & $.101 \pm 0.410$ & $.057 \pm 0.231$ & $0 \pm 2$ \\
MV-35 & $1.40 \pm 0.707$ & $.970 \pm 0.490$ & $-.396 \pm 0.342$ & $-.209 \pm 0.190$ & $0 \pm 2$ \\
MV-36 & $3.07 \pm 1.03$ & $2.10 \pm 0.699$ & $.084 \pm 0.253$ & $.046 \pm 0.142$ & $0 \pm 2$ \\
MV-38 & $1.91 \pm 0.899$ & $1.19 \pm 0.575$ & $-.239 \pm 0.291$ & $-.126 \pm 0.160$ & $2 \pm 2$ \\
MV-44* & $1.84 \pm 0.798$ & $1.27 \pm 0.554$ & $.010 \pm 0.387$ & $.005 \pm 0.203$ & $0 \pm 2$ \\
MV-46 & $1.79 \pm 0.843$ & $1.10 \pm 0.535$ & $-.302 \pm 0.384$ & $-.163 \pm 0.213$ & $0 \pm 2$ \\
MV-50 & $4.48 \pm 1.26$ & $3.09 \pm 0.865$ & $-.028 \pm 0.301$ & $-.015 \pm 0.162$ & $2 \pm 2$ \\
MV-53 & $4.04 \pm 1.22$ & $2.89 \pm 0.872$ & $-.046 \pm 0.378$ & $-.025 \pm 0.207$ & $2 \pm 2$ \\
MV-55 & $2.26 \pm 0.909$ & $1.57 \pm 0.633$ & $-.321 \pm 0.409$ & $-.168 \pm 0.216$ & $-1 \pm 2$ \\
MV-57 & $1.95 \pm 0.831$ & $1.34 \pm 0.576$ & $-.255 \pm 0.380$ & $-.139 \pm 0.213$ & $0 \pm 2$ \\
MV-58 & $1.47 \pm 0.723$ & $1.02 \pm 0.500$ & $.480 \pm 0.570$ & $.258 \pm 0.344$ & $0 \pm 2$ \\
MV-60* & $3.40 \pm 1.13$ & $2.39 \pm 0.801$ & $-.094 \pm 0.365$ & $-.050 \pm 0.197$ & $0 \pm 2$ \\
\hline
\end{tabular}


Table 6.-Concentrations of gross beta-particle radioactivity in water from selected wells and springs, eastern Snake River Plain

[See figure 2 for location of sites. Analyses were performed by the U.S. Geological Survey National Water Quality Laboratory (NWQL) and Idaho State University (ISU) Environmental Monitoring Laboratory using a residue procedure. Analytical results and uncertainties-for example 4.33 \pm 1.28 - in picocuries per liter. Analytical uncertainties are reported as $2 \mathrm{~s}$. Abbreviation: Sr-90/Y-90, strontium-90 in equilibrium with yttrium-90. Symbol: *, quality assurance sample (MV-44 is a replicate of MV-46; MV-60 is a replicate of MV-36)]

\begin{tabular}{|c|c|c|c|c|c|}
\hline Site identifier & $\begin{array}{l}\text { Dissolved as } \\
\text { cesium-137 } \\
\text { NWQL }\end{array}$ & $\begin{array}{c}\text { Dissolved as } \\
\text { Sr-90/Y-90 } \\
\text { NWQL }\end{array}$ & $\begin{array}{l}\text { Suspended as } \\
\text { cesium-137 } \\
\text { NWQL }\end{array}$ & $\begin{array}{c}\text { Suspended as } \\
\text { Sr-90/Y-90 } \\
\text { NWQL }\end{array}$ & $\begin{array}{l}\text { Total as } \\
\text { cesium-137 } \\
\text { ISU }\end{array}$ \\
\hline MV-03 & $4.33 \pm 1.28$ & $3.15 \pm 1.27$ & $0.140 \pm 0.458$ & $0.136 \pm 0.446$ & $6 \pm 4$ \\
\hline MV-05 & $6.69 \pm 1.51$ & $5.05 \pm 1.14$ & $-.109 \pm 0.502$ & $-.105 \pm 0.480$ & $4 \pm 4$ \\
\hline MV-06 & $8.01 \pm 1.63$ & $6.07 \pm 1.24$ & $.313 \pm 0.508$ & $.296 \pm 0.479$ & $7 \pm 4$ \\
\hline MV-07 & $4.00 \pm 1.26$ & $2.93 \pm 0.792$ & $.232 \pm 0.468$ & $.219 \pm 0.442$ & $7 \pm 4$ \\
\hline MV-13 & $7.50 \pm 1.54$ & $5.59 \pm 1.15$ & $.260 \pm 0.464$ & $.252 \pm 0.449$ & $7 \pm 4$ \\
\hline MV-17 & $4.15 \pm 1.24$ & $3.02 \pm 0.794$ & $.027 \pm 0.495$ & $.025 \pm 0.473$ & $1 \pm 4$ \\
\hline MV-20 & $4.51 \pm 1.14$ & $3.46 \pm 0.872$ & $.479 \pm 0.490$ & $.466 \pm 0.477$ & $2 \pm 4$ \\
\hline MV-27 & $6.73 \pm 1.51$ & $5.02 \pm 1.12$ & $.164 \pm 0.458$ & $.154 \pm 0.432$ & $5 \pm 4$ \\
\hline MV-31 & $7.32 \pm 1.55$ & $5.46 \pm 1.16$ & $.394 \pm 0.503$ & $.383 \pm 0.489$ & $7 \pm 4$ \\
\hline MV-35 & $2.89 \pm 0.840$ & $2.32 \pm 0.674$ & $.193 \pm 0.453$ & $.187 \pm 0.439$ & $6 \pm 4$ \\
\hline MV-36 & $4.80 \pm 1.18$ & $3.66 \pm 0.899$ & $.481 \pm 0.506$ & $.460 \pm 0.484$ & $6 \pm 4$ \\
\hline MV-38 & $3.87 \pm 1.21$ & $2.86 \pm 1.10$ & $.447 \pm 0.501$ & $.428 \pm 0.480$ & $1 \pm 4$ \\
\hline MV-44* & $2.79 \pm 0.959$ & $2.09 \pm 0.652$ & $.308 \pm 0.445$ & $.295 \pm 0.426$ & $3 \pm 4$ \\
\hline MV-46 & $4.17 \pm 1.25$ & $3.13 \pm 0.776$ & $.119 \pm 0.511$ & $.112 \pm 0.483$ & $2 \pm 4$ \\
\hline MV-50 & $8.75 \pm 1.77$ & $6.52 \pm 1.32$ & $.224 \pm 0.444$ & $.211 \pm 0.419$ & $8 \pm 4$ \\
\hline MV-53 & $9.94 \pm 2.06$ & $7.38 \pm 1.53$ & $.368 \pm 0.489$ & $.347 \pm 0.461$ & $9 \pm 4$ \\
\hline MV-55 & $3.55 \pm 1.10$ & $2.60 \pm 0.716$ & $.495 \pm 0.492$ & $.481 \pm 0.479$ & $5 \pm 4$ \\
\hline MV-57 & $2.81 \pm 0.848$ & $2.22 \pm 0.670$ & $.616 \pm 0.502$ & $.590 \pm 0.480$ & $3 \pm 4$ \\
\hline MV-58 & $3.56 \pm 0.968$ & $2.76 \pm 0.751$ & $.091 \pm 0.494$ & $.089 \pm 0.481$ & $4 \pm 4$ \\
\hline MV-60* & $4.63 \pm 1.17$ & $3.47 \pm 0.877$ & $.348 \pm 0.471$ & $.339 \pm 0.458$ & $4 \pm 4$ \\
\hline
\end{tabular}


Table 7.-Dissolved concentrations of total uranium and selected radium isotopes in water from selected wells and springs, eastern Snake River Plain

[See figure 2 for location of sites. Analyses were performed by the U.S. Geological Survey National Water Quality Laboratory using the following methods: total uranium by extraction and laser-induced phosphorimetry; radium- 226 by radon emanation; and radium- 228 by separation and beta counting. Analytical results and uncertainties - for example $1.75 \pm 0.263$ - in indicated units. Analytical uncertainties are reported as $2 \mathrm{~s}$. Abbreviations: $\mu \mathrm{g} / \mathrm{L}$, microgram per liter; pCi/L, picocurie per liter. Symbol: *, quality assurance sample (MV-44 is a replicate of MV-46; $\mathrm{MV}-60$ is a replicate of $\mathrm{MV}-36)]$

\begin{tabular}{|c|c|c|c|}
\hline Site identifier & $\begin{array}{l}\text { Total uranium } \\
(\mu \mathrm{g} / \mathrm{L})\end{array}$ & $\begin{array}{l}\text { Radium-226 } \\
(\mathrm{pCi} / \mathrm{L})\end{array}$ & $\begin{array}{l}\text { Radium-228 } \\
\quad(\mathrm{pCi} / \mathrm{L})\end{array}$ \\
\hline MV-03 & $1.75 \pm 0.263$ & $0.024 \pm 0.009$ & $0.454 \pm 0.324$ \\
\hline MV-05 & $2.80 \pm 0.420$ & $.031 \pm 0.011$ & $.041 \pm 0.235$ \\
\hline MV-06 & $2.05 \pm 0.308$ & $.028 \pm 0.011$ & $.732 \pm 0.386$ \\
\hline MV-07 & $1.43 \pm 0.214$ & $.004 \pm 0.211$ & $.042 \pm 0.013$ \\
\hline MV-13 & $2.83 \pm 0.424$ & $.034 \pm 0.010$ & $.195 \pm 0.267$ \\
\hline MV-17 & $1.74 \pm 0.260$ & $.023 \pm 0.008$ & $.274 \pm 0.302$ \\
\hline MV-20 & $2.05 \pm 0.307$ & $.022 \pm 0.008$ & $.238 \pm 0.307$ \\
\hline MV-27 & $2.65 \pm 0.398$ & $.036 \pm 0.010$ & $.371 \pm 0.310$ \\
\hline MV-31 & $2.46 \pm 0.370$ & $.033 \pm 0.014$ & $.332 \pm 0.346$ \\
\hline MV-35 & $1.22 \pm 0.182$ & $.010 \pm 0.011$ & $.419 \pm 0.317$ \\
\hline MV-36 & $3.16 \pm 0.474$ & $.024 \pm 0.008$ & $.100 \pm 0.275$ \\
\hline MV-38 & $2.58 \pm 0.386$ & $.026 \pm 0.008$ & $.155 \pm 0.318$ \\
\hline MV-44* & $1.65 \pm 0.247$ & $.049 \pm 0.015$ & $.226 \pm 0.283$ \\
\hline MV-46 & $1.36 \pm 0.205$ & $.035 \pm 0.014$ & $.227 \pm 0.296$ \\
\hline MV-50 & $3.18 \pm 0.477$ & $.059 \pm 0.015$ & $.375 \pm 0.307$ \\
\hline MV-53 & $3.30 \pm 0.495$ & $.035 \pm 0.009$ & $1.62+0.590$ \\
\hline MV-55 & $1.81 \pm 0.272$ & $.026 \pm 0.009$ & $.917 \pm 0.473$ \\
\hline MV-57 & $1.08 \pm 0.162$ & $.028 \pm 0.009$ & $.468 \pm 0.309$ \\
\hline MV-58 & $1.18 \pm 0.177$ & $.028 \pm 0.008$ & $.107 \pm 0.223$ \\
\hline MV-60* & $3.10 \pm 0.465$ & $.061 \pm 0.013$ & $.216 \pm 0.340$ \\
\hline
\end{tabular}


The sum of radium-226 and radium-228 concentrations in each of the water samples was less than the maximum contaminant level of $5 \mathrm{pCi} / \mathrm{L}$ (table 3).

\section{Cesium-137, Radium-226, Uranium-235, Uranium-238, and Potassium-40}

Gamma spectrometry involves using a series of detectors to simultaneously determine the concentrations of a variety of radionuclides by the identification of their characteristic gamma emissions. Total and suspended fractions of cesium-137 and suspended fractions of radium-226, uranium-235, uranium-238, and potassium-40 were identified in water samples. The NWQL reported the radionuclides as suspended fractions, whereas ISU reported them as total.

Cesium-137 is a fission product of uranium-235, uranium-233, or plutonium-239. Cesium-137 was identified in all of the samples analyzed by the NWQL and ISU, but none had concentrations of cesium-137 that exceeded the reporting level (table 8).

Radium-226 is a decay product of thorium- 230 in the uranium-238 decay series. Radium-226 was identified in seven water samples; five samples had concentrations greater than the reporting levels and ranged from $0.280 \pm 0.175$ to $0.592 \pm 0.188 \mathrm{pCi} / \mathrm{L}$ (table 8 ).

Uranium-235 is a naturally occurring radioactive isotope. Uranium-235 was identified in two water samples. One sample, MV-38, exceeded the reporting level with a concentration of $0.532 \pm 0.319 \mathrm{pCi} / \mathrm{L}$ (table 8 ).

Uranium-238 is a naturally occurring radioactive isotope. Uranium-238 was identified in 10 samples; 8 samples had concentrations greater than the reporting levels and ranged from $0.356 \pm 0.186$ to $0.497 \pm 0.175 \mathrm{pCi} / \mathrm{L}$ (table 8 ).

Potassium makes up approximately 2.6 percent of the Earth's continental crust, and about 0.0119 percent of all potassium is the naturally occurring radioactive isotope potassium -40 (Kretz, 1972). Potassium-40 was identified in 11 water samples; 8 samples had concentrations greater than the reporting levels and ranged from $4.32 \pm 1.44$ to $20.8 \pm 2.94 \mathrm{pCi} / \mathrm{L}$ (table 8 ).

\section{INORGANIC CONSTITUENTS}

Water samples were analyzed for selected inorganic constituents. These constituents included trace elements, common ions, nutrients, and cyanide. In this report, reporting levels established for these constituents are not to be confused with reporting levels and analytical method detection limits for selected radionuclides. The reporting level for inorganic constituents is the lowest measured concentration of a constituent that may be reliably reported using a given analytical method (Pritt and Jones, 1989).

\section{Trace Elements}

Water samples were collected and analyzed by the NWQL and the IDHWL for selected dissolved trace elements including aluminum, arsenic, barium, beryllium, cadmium, chromium, cobalt, copper, iron, lead, lithium, manganese, mercury, molybdenum, nickel, selenium, silver, strontium, vanadium, and zinc. Water samples also were analyzed for hexavalent and total chromium by the NWQL. The maximum contaminant levels and reporting levels for selected trace elements are shown on table 9. The concentrations of dissolved trace elements and hexavalent and total chromium are shown on table 10.

Aluminum.-Concentrations of aluminum in 11 samples analyzed by the NWQL were equal to or greater than the reporting level and ranged from 10 to $30 \mu \mathrm{g} / \mathrm{L}$. Concentrations of all the samples analyzed by the IDHWL were less than the reporting level of $100 \mu \mathrm{g} / \mathrm{L}$. The proposed secondary maximum contaminant level is $50 \mu \mathrm{g} / \mathrm{L}$.

Arsenic--Concentrations of arsenic in all samples analyzed by the NWQL were equal to or greater than the reporting level and ranged from 1 to $4 \mu \mathrm{g} / \mathrm{L}$. Concentrations of arsenic in all samples analyzed by the IDHWL were less than the reporting level of $10 \mu \mathrm{g} / \mathrm{L}$. The maximum contaminant level is $50 \mu \mathrm{g} / \mathrm{L}$. 
Table 8.-Concentrations of cesium-137, radium-226, uranium-235, uranium-238, and potassium-40 in water from selected wells and springs, eastern Snake River Plain

[See figure 2 for location of sites. Analyses were performed by the U.S. Geological Survey

National Water Quality Laboratory (NWQL) and the Idaho State University (ISU) Environmental Monitoring Laboratory using gamma spectrometry. Analytical results and uncertainties from NWQL-for example - $0.0221 \pm 0.0912$ - are for suspended concentrations in picocuries per liter $(\mathrm{pCi} / \mathrm{L})$. Analytical results and uncertainties from ISU are for total concentrations in $\mathrm{pCi} / \mathrm{L}$. Analytical uncertainties are reported as 2 s. Symbols: **, radionuclide was not identified in that sample; *, quality assurance sample (MV-44 is a replicate of MV-46; MV-60 is a replicate of MV-36)]

\begin{tabular}{|c|c|c|c|c|c|c|}
\hline $\begin{array}{c}\text { Site } \\
\text { identifier }\end{array}$ & $\begin{array}{c}\text { Cesium-137 } \\
\text { NWQL }\end{array}$ & $\begin{array}{l}\text { Cesium-137 } \\
\text { ISU }\end{array}$ & $\begin{array}{l}\text { Radium-226 } \\
\text { NWQL. }\end{array}$ & $\begin{array}{c}\text { Uranium- } \\
235 \\
\text { NWQL }\end{array}$ & $\begin{array}{c}\text { Uranium- } \\
238 \\
\text { NWQL }\end{array}$ & $\begin{array}{c}\text { Potassium- } \\
40 \\
\text { NWQL }\end{array}$ \\
\hline MV-03 & $-0.0221 \pm 0.0912$ & $1.6 \pm 2.4$ & $* *$ & $* *$ & $0.227 \pm 0.175$ & $5.80 \pm 1.50$ \\
\hline MV-05 & $.0149 \pm 0.0984$ & $1.2 \pm 2.0$ & $* *$ & $* *$ & $.429 \pm 0.195$ & $4.32 \pm 1.44$ \\
\hline MV-06 & $.0666 \pm 0.0939$ & $-.8 \pm 1.8$ & $* *$ & $* *$ & $* *$ & ** \\
\hline MV-07 & $.00688 \pm 0.0962$ & $.6 \pm 2.4$ & $* *$ & $* *$ & $.356 \pm 0.186$ & $6.72 \pm 1.74$ \\
\hline MV-13 & $.024 \pm 0.092$ & $1.0 \pm 2.2$ & $0.211 \pm 0.191$ & $* *$ & $* *$ & $* *$ \\
\hline MV-17 & $-.0169 \pm 0.0870$ & $-.6 \pm 2.2$ & $* *$ & $* *$ & $.422+0.180$ & $* *$ \\
\hline MV-20 & $.0171 \pm 0.0973$ & $.2 \pm 2.2$ & $* *$ & $* *$ & $* *$ & $8.03 \pm 1.58$ \\
\hline MV-27 & $.0145 \pm 0.0918$ & $.3 \pm 2.4$ & $* *$ & $0.429 \pm 0.371$ & $.443 \pm 0.181$ & $20.8 \pm 2.94$ \\
\hline MV-31 & $.0012 \pm 0.088$ & $-1.4 \pm 2.2$ & $.215 \pm 0.212$ & $* *$ & $* *$ & $* *$ \\
\hline MV-35 & $.021 \pm 0.087$ & $-.4 \pm 2.0$ & $.280+0.175$ & $* *$ & $* *$ & $* *$ \\
\hline MV-36 & $.0314 \pm 0.0960$ & $.5 \pm 2.2$ & $* *$ & $* *$ & $* *$ & $1.48 \pm 2.36$ \\
\hline MV-38 & $-.0130 \pm 0.0840$ & $2.7 \pm 2.2$ & $* *$ & $.532+0.319$ & $.469 \div 0.164$ & $11.1 \pm 1.97$ \\
\hline MV-44* & $.014 \pm 0.090$ & $.4 \pm 2.4$ & $.317 \pm 0.200$ & $* *$ & $* *$ & $* *$ \\
\hline MV-46 & $.007 \pm 0.087$ & $.3 \pm 2.2$ & $.351 \pm 0.196$ & $* *$ & $* *$ & $* *$ \\
\hline MV-50 & $-.0293 \pm 0.100$ & $-.9 \pm 1.8$ & $* *$ & $* *$ & $.445 \pm 0.192$ & $7.81 \pm 1.83$ \\
\hline MV-53 & $.0989 \pm 0.0975$ & $.3 \pm 2.0$ & $* *$ & $* *$ & $.230 \pm 0.172$ & $.892 \pm 2.32$ \\
\hline MV-55 & $-.0477 \pm 0.102$ & $-.7 \pm 2.0$ & $* *$ & $* *$ & $.414 \pm 0.188$ & $7.74 \pm 1.74$ \\
\hline MV-57 & $.018 \pm 0.083$ & $-2.7 \pm 2.0$ & $.348 \pm 0.191$ & $* *$ & $* *$ & $* *$ \\
\hline MV-58 & $-.091 \pm 0.091$ & $-.4 \pm 2.4$ & $.592+0.188$ & $* *$ & $* *$ & $* *$ \\
\hline MV-60* & $-.0507 \pm 0.0917$ & $.2 \pm 1.8$ & $* *$ & $* *$ & $.497 \pm 0.175$ & $1.56 \pm 3.22$ \\
\hline
\end{tabular}




\section{Table 9.--Maximum contaminant levels and reporting levels of selected trace elements in drinking water}

[The maximum contaminant levels are for total measurements and were established pursuant to the recommendations of the U.S. Environmental Protection Agency (1989, p. 547) for community water systems and are for comparison purposes only. Proposed maximum contaminant levels-in parentheses_are from U.S. Environmental Protection Agency (1990a, 1991b). Proposed secondary and secondary maximum contaminant levels-in brackets-are from U.S. Environmental Protection Agency $(1989,1990$ a). Reporting levels for the U.S. Geological Survey National Water Quality Laboratory (NWQL) are from Pritt and Jones (1989). Reporting levels for the Idaho Department of Health and Welfare Laboratory (IDHWL) are from J. Dodds, (written commun., 1991). Units are in microgram per liter $(\mu \mathrm{g} / \mathrm{L})$. Symbols: $* *$, analysis not requested; --, maximum contaminant level has not been established for the chemical constituent]

\begin{tabular}{|c|c|c|c|}
\hline Constituent & $\begin{array}{c}\text { Maximum contaminant } \\
\text { level }\end{array}$ & $\begin{array}{l}\text { Reporting level } \\
\text { NWQL }\end{array}$ & $\begin{array}{l}\text { Reporting level } \\
\text { IDHWL }\end{array}$ \\
\hline Aluminum & [50] & 10 & 100 \\
\hline Arsenic & $\begin{array}{c}50 \\
(30)\end{array}$ & 1 & 10 \\
\hline Barium & $\begin{array}{c}1,000 \\
(2,000)\end{array}$ & 2 & 100 \\
\hline Beryllium & (1) & .5 & 5 \\
\hline Cadmium & $\begin{array}{l}10 \\
(5)\end{array}$ & 1 & 1 \\
\hline Chromium, total & $\begin{array}{c}50 \\
(100)\end{array}$ & 1 & ** \\
\hline Chromium, dissolved & -- & 5 & 2 \\
\hline Chromium, hexavalent & -- & 1 & $* *$ \\
\hline Cobalt & -- & 3 & 10 \\
\hline Copper & $(1,300)$ & 10 & 10 \\
\hline Iron & $\begin{array}{c}{[300]} \\
--\end{array}$ & 3 & 10 \\
\hline Lead & $\begin{array}{l}50 \\
(5)\end{array}$ & 1 & 5 \\
\hline Lithium & -- & 4 & 10 \\
\hline Manganese & $\begin{array}{c}{[50]} \\
--\end{array}$ & 1 & 10 \\
\hline Mercury & 2 & .1 & 5 \\
\hline Molybdenum & - & 10 & 10 \\
\hline Nickel & (100) & 10 & 10 \\
\hline Selenium & $\begin{array}{c}10 \\
(50)\end{array}$ & 1 & 5 \\
\hline Silver & $\begin{array}{c}50 \\
{[90]}\end{array}$ & 1 & 1 \\
\hline Strontium & -- & 1 & 1 \\
\hline Vanadium & -- & 6 & 10 \\
\hline Zinc & -- & 3 & 2 \\
\hline
\end{tabular}


Table 10.-Concentrations of dissolved trace elements and hexavalent and total chromium in water from selected wells and springs, eastern Snake River Plain

[See figure 2 for location of sites. Analyses were performed by the U.S. Geological Survey National Water Quality Laboratory (NWQL) and the Idaho Department of Health and Welfare Laboratory (IDHWL). Analytical results in micrograms per liter $(\mu \mathrm{g} / \mathrm{L})$. Symbols: <, concentration was less than the respective reporting level; *, quality assurance sample (MV-44 is a replicate of MV-46; MV-60 is a replicate of MV-36, MV-62A and B are equipment blanks collected on 6/24/92 and 7/30/92, respectively); --, no analysis was performed]

\begin{tabular}{|c|c|c|c|c|c|c|c|c|}
\hline $\begin{array}{c}\text { Site } \\
\text { identifier }\end{array}$ & $\begin{array}{l}\text { Aluminum } \\
\text { NWQL }\end{array}$ & $\begin{array}{l}\text { Aluminum } \\
\text { IDHWL }\end{array}$ & $\begin{array}{l}\text { Arsenic } \\
\text { NWQL }\end{array}$ & $\begin{array}{l}\text { Arsenic } \\
\text { IDHWL }\end{array}$ & $\begin{array}{l}\text { Barium } \\
\text { NWQL }\end{array}$ & $\begin{array}{l}\text { Barium } \\
\text { DHWL }\end{array}$ & $\begin{array}{l}\text { Beryllium } \\
\text { NWQL }\end{array}$ & $\begin{array}{l}\text { Beryllium } \\
\text { IDWHL }\end{array}$ \\
\hline MV-03 & 20 & $<100$ & 2 & $<10$ & 21 & $<100$ & $<0.5$ & $<5$ \\
\hline MV-05 & $<10$ & $<100$ & 3 & $<10$ & 48 & $<100$ & .9 & $<5$ \\
\hline MV-06 & 10 & $<100$ & 3 & $<10$ & 77 & $<100$ & $<.5$ & $<5$ \\
\hline MV-07 & 20 & $<100$ & 2 & $<10$ & 20 & $<100$ & $<.5$ & $<5$ \\
\hline MV-13 & $<10$ & $<100$ & 4 & $<10$ & 82 & 100 & $<.5$ & $<5$ \\
\hline MV-17 & 10 & $<100$ & 2 & $<10$ & 22 & $<100$ & $<.5$ & $<5$ \\
\hline MV-20 & 30 & $<100$ & 2 & $<10$ & 21 & $<100$ & $<.5$ & $<5$ \\
\hline MV-27 & 10 & $<100$ & 2 & $<10$ & 54 & $<100$ & $<.5$ & $<5$ \\
\hline MV-31 & $<10$ & $<100$ & 2 & $<10$ & 49 & 100 & $<.5$ & $<5$ \\
\hline MV-35 & $<10$ & $<100$ & 2 & $<10$ & 12 & $<100$ & $<.5$ & $<5$ \\
\hline MV-36 & 20 & $<100$ & 2 & $<10$ & 43 & $<100$ & .8 & $<5$ \\
\hline MV-38 & 10 & $<100$ & 1 & $<10$ & 28 & $<100$ & $<.5$ & $<5$ \\
\hline MV-44* & $<10$ & $<100$ & 2 & $<10$ & 16 & $<100$ & $<.5$ & $<5$ \\
\hline MV-46 & $<10$ & $<100$ & 2 & $<10$ & 16 & $<100$ & $<.5$ & $<5$ \\
\hline MV-50 & 20 & $<100$ & 3 & $<10$ & 57 & 100 & $<.5$ & $<5$ \\
\hline MV-53 & $<10$ & $<100$ & 2 & $<10$ & 91 & 100 & $<.5$ & $<5$ \\
\hline MV-55 & $<10$ & $<100$ & 2 & $<10$ & 22 & $<100$ & 1.1 & $<5$ \\
\hline MV-57 & $<10$ & $<100$ & 2 & $<10$ & 5 & $<100$ & $<.5$ & $<5$ \\
\hline MV-58 & 10 & $<100$ & 3 & $<10$ & 19 & $<100$ & $<.5$ & $<5$ \\
\hline MV-60* & 10 & $<100$ & 2 & $<10$ & 44 & $<100$ & .9 & $<5$ \\
\hline MV-62A* & -- & $<100$ & -- & $<10$ & -- & $<100$ & -- & $<5$ \\
\hline MV- $62 B^{*}$ & -- & $<100$ & -- & $<10$ & -- & $<100$ & -- & $<5$ \\
\hline
\end{tabular}


Table 10. Concentrations of dissolved trace elements and hexavalent and total chromium in water from selected wells and springs, eastern Snake River Plain-Continued

\begin{tabular}{|c|c|c|c|c|c|c|c|c|}
\hline \multirow[b]{2}{*}{$\begin{array}{c}\text { Site } \\
\text { identifier }\end{array}$} & \multirow[b]{2}{*}{$\begin{array}{l}\text { Cadmium } \\
\text { NWQL }\end{array}$} & \multirow[b]{2}{*}{$\begin{array}{l}\text { Cadmium } \\
\text { IDHWL }\end{array}$} & \multicolumn{4}{|c|}{ Chromium } & \multirow[b]{2}{*}{$\begin{array}{l}\text { Cobalt } \\
\text { NWQL }\end{array}$} & \multirow[b]{2}{*}{$\begin{array}{l}\text { Cobalt } \\
\text { IDHWL }\end{array}$} \\
\hline & & & $\begin{array}{l}\text { dissolved } \\
\text { NWQL }\end{array}$ & $\begin{array}{l}\text { dissolved } \\
\text { IDHWL }\end{array}$ & $\begin{array}{l}\text { hexavalent } \\
\text { NWQL }\end{array}$ & $\begin{array}{c}\text { total } \\
\text { NWQL }\end{array}$ & & \\
\hline MV-03 & $<1$ & $<1$ & $<5$ & 2.6 & $<1$ & 4 & $<3$ & $<10$ \\
\hline MV-05 & $<1$ & $<1$ & $<5$ & 2.2 & $<1$ & $<1$ & $<3$ & $<10$ \\
\hline MV-06 & $<1$ & $<1$ & $<5$ & $<2$ & $<1$ & 4 & $<3$ & $<10$ \\
\hline MV-07 & 1 & $<1$ & $<5$ & 2.5 & 1 & $<1$ & $<3$ & $<10$ \\
\hline MV-13 & $<1$ & $<1$ & $<5$ & $<2$ & $<1$ & 2 & $<3$ & $<10$ \\
\hline MV-17 & $<1$ & $<1$ & $<5$ & 3.0 & $<1$ & 2 & $<3$ & $<10$ \\
\hline MV-20 & $<1$ & $<1$ & $<5$ & 3.1 & $<1$ & $<1$ & $<3$ & $<10$ \\
\hline MV-27 & $<1$ & $<1$ & $<5$ & 2.7 & $<1$ & $<1$ & $<3$ & $<10$ \\
\hline MV-31 & $<1$ & $<1$ & $<5$ & 2.3 & $<1$ & $<1$ & $<3$ & $<10$ \\
\hline MV-35 & $<1$ & $<1$ & $<5$ & 4.1 & 4 & 5 & $<3$ & $<10$ \\
\hline MV-36 & $<1$ & $<1$ & $<5$ & $<2$ & $<1$ & 2 & $<3$ & $<10$ \\
\hline MV-38 & 1 & $<1$ & $<5$ & $<2$ & $<1$ & 1 & $<3$ & $<10$ \\
\hline MV-44 & $<1$ & $<1$ & $<5$ & 3.9 & 2 & 3 & $<3$ & $<10$ \\
\hline MV-46 & $<1$ & $<1$ & $<5$ & 3.8 & 2 & 1 & $<3$ & $<10$ \\
\hline MV-50 & $<1$ & $<1$ & $<5$ & 2.0 & $<1$ & 1 & $<3$ & $<10$ \\
\hline MV-53 & $<1$ & $<1$ & $<5$ & $<2$ & $<1$ & $<1$ & $<3$ & $<10$ \\
\hline MV-55 & 2 & $<1$ & $<5$ & 3.5 & $<1$ & 1 & $<3$ & $<10$ \\
\hline MV-57 & $<1$ & $<1$ & $<5$ & 3.2 & 1 & 3 & $<3$ & $<10$ \\
\hline MV-58 & $<1$ & $<1$ & $<5$ & 2.7 & 1 & 4 & $<3$ & $<10$ \\
\hline MV-60* & $<1$ & $<1$ & $<5$ & $<2$ & $<1$ & $<1$ & $<3$ & $<10$ \\
\hline MV-62A* & -- & $<1$ & -- & $<2$ & -- & - & - & $<10$ \\
\hline MV-62B* & -- & $<1$ & - & $<2$ & -- & -- & -- & $<10$ \\
\hline
\end{tabular}


Table 10.-Concentrations of dissolved trace elements and hexavalent and total chromium in water from selected wells and springs, eastern Snake River Plain-Continued

\begin{tabular}{|c|c|c|c|c|c|c|c|c|}
\hline $\begin{array}{c}\text { Site } \\
\text { identifier }\end{array}$ & $\begin{array}{l}\text { Copper } \\
\text { NWQL }\end{array}$ & $\begin{array}{l}\text { Copper } \\
\text { IDHWL }\end{array}$ & $\begin{array}{c}\text { Iron } \\
\text { NWQL }\end{array}$ & $\begin{array}{c}\text { Iron } \\
\text { IDHWL }\end{array}$ & $\begin{array}{l}\text { Lead } \\
\text { NWQL }\end{array}$ & $\begin{array}{l}\text { Lead } \\
\text { IDHWL }\end{array}$ & $\begin{array}{l}\text { Lithium } \\
\text { NWQL }\end{array}$ & $\begin{array}{l}\text { Lithium } \\
\text { IDHWL }\end{array}$ \\
\hline MV-03 & $<10$ & $<10$ & $<3$ & $<10$ & $<1$ & $<5$ & 31 & 30 \\
\hline MV-05 & $<10$ & $<10$ & 4 & $<10$ & $<1$ & $<5$ & 40 & 50 \\
\hline MV-06 & $<10$ & $<10$ & $<3$ & $<10$ & $<1$ & $<5$ & 38 & 40 \\
\hline MV-07 & $<10$ & $<10$ & $<3$ & $<10$ & $<1$ & $<5$ & 26 & 30 \\
\hline MV-13 & $<10$ & $<10$ & $<3$ & $<10$ & $<1$ & $<5$ & 28 & 20 \\
\hline MV-17 & $<10$ & $<10$ & $<3$ & $<10$ & $<1$ & $<5$ & 27 & 30 \\
\hline MV-20 & $<10$ & $<10$ & 4 & $<10$ & $<1$ & $<5$ & 20 & 20 \\
\hline MV-27 & $<10$ & $<10$ & $<3$ & $<10$ & $<1$ & $<5$ & 41 & 50 \\
\hline MV-31 & $<10$ & $<10$ & $<3$ & $<10$ & $<1$ & $<5$ & 37 & 30 \\
\hline MV-35 & $<10$ & $<10$ & $<3$ & $<10$ & $<1$ & $<5$ & 12 & 10 \\
\hline MV-36 & $<10$ & $<10$ & 9 & $<10$ & $<1$ & $<5$ & 6 & 10 \\
\hline MV-38 & $<10$ & $<10$ & 10 & $<10$ & $<1$ & $<5$ & 8 & 10 \\
\hline MV-44 & $<10$ & $<10$ & $<3$ & $<10$ & $<1$ & $<5$ & 12 & 10 \\
\hline MV-46 & $<10$ & $<10$ & $<3$ & $<10$ & $<1$ & $<5$ & 12 & 10 \\
\hline MV-50 & $<10$ & $<10$ & $<3$ & $<10$ & $<1$ & $<5$ & 38 & 40 \\
\hline MV-53 & $<10$ & $<10$ & $<3$ & $<10$ & $<1$ & $<5$ & 53 & 60 \\
\hline MV-55 & $<10$ & $<10$ & $<3$ & $<10$ & $<1$ & $<5$ & 27 & 30 \\
\hline MV-57 & $<10$ & $<10$ & 9 & $<10$ & $<1$ & $<5$ & 5 & $<10$ \\
\hline MV-58 & $<10$ & $<10$ & 18 & $<10$ & $<1$ & $<5$ & 6 & $<10$ \\
\hline MV-60* & $<10$ & $<10$ & 17 & $<10$ & $<1$ & $<5$ & 6 & 10 \\
\hline MV-62A* & - & $<10$ & - & $<10$ & -- & $<5$ & - & $<10$ \\
\hline MV-62B* & - & $<10$ & -- & $<10$ & -- & $<5$ & -- & $<10$ \\
\hline
\end{tabular}


Table 10. Concentrations of dissolved trace elements and hexavalent and total chromium in water from selected wells and springs, eastern Snake River Plain-Continued

\begin{tabular}{|c|c|c|c|c|c|c|}
\hline $\begin{array}{c}\text { Site } \\
\text { identifier }\end{array}$ & $\begin{array}{l}\text { Manganese } \\
\text { NWQL }\end{array}$ & $\begin{array}{l}\text { Manganese } \\
\text { IDHWL }\end{array}$ & $\begin{array}{l}\text { Mercury } \\
\text { NWQL }\end{array}$ & $\begin{array}{l}\text { Mercury } \\
\text { IDHWL }\end{array}$ & $\begin{array}{l}\text { Molybdenum } \\
\text { NWQL }\end{array}$ & $\begin{array}{l}\text { Molybdenum } \\
\text { IDHWL }\end{array}$ \\
\hline MV-03 & $<1$ & $<10$ & $<0.1$ & $<0.5$ & $<10$ & $<10$ \\
\hline MV-05 & $<1$ & $<10$ & $<.1$ & $<.5$ & $<10$ & $<10$ \\
\hline MV-06 & $<1$ & $<10$ & $<.1$ & $<.5$ & $<10$ & $<10$ \\
\hline MV-07 & $<1$ & $<10$ & $<.1$ & $<.5$ & $<10$ & $<10$ \\
\hline MV-13 & $<1$ & $<10$ & $<.1$ & $<.5$ & $<10$ & $<10$ \\
\hline MV-17 & $<1$ & $<10$ & $<.1$ & $<.5$ & $<10$ & $<10$ \\
\hline MV-20 & $<1$ & $<10$ & $<.1$ & $<.5$ & $<10$ & $<10$ \\
\hline MV-27 & $<1$ & $<10$ & $<.1$ & $<.5$ & $<10$ & $<10$ \\
\hline MV-31 & $<1$ & $<10$ & $<.1$ & $<.5$ & $<10$ & $<10$ \\
\hline MV-35 & $<1$ & $<10$ & $<.1$ & $<.5$ & $<10$ & $<10$ \\
\hline MV-36 & $<1$ & $<10$ & $<.1$ & $<.5$ & $<10$ & $<10$ \\
\hline MV-38 & $<1$ & $<10$ & $<.1$ & $<.5$ & $<10$ & $<10$ \\
\hline MV-44* & $<1$ & $<10$ & $<.1$ & $<.5$ & $<10$ & $<10$ \\
\hline MV-46 & $<1$ & $<10$ & $<.1$ & $<.5$ & 10 & $<10$ \\
\hline MV-50 & $<1$ & $<10$ & $<.1$ & $<.5$ & $<10$ & $<10$ \\
\hline MV-53 & $<1$ & $<10$ & $<.1$ & $<.5$ & $<10$ & $<10$ \\
\hline MV-55 & $<1$ & $<10$ & $<.1$ & $<.5$ & $<10$ & $<10$ \\
\hline MV-57 & 3 & $<10$ & $<.1$ & $<.5$ & $<10$ & $<10$ \\
\hline MV-58 & 5 & $<10$ & $<.1$ & $<.5$ & $<10$ & $<10$ \\
\hline MV- $60^{*}$ & $<1$ & $<10$ & $<.1$ & $<.5$ & $<10$ & $<10$ \\
\hline MV-62A* & - & $<10$ & -- & $<.5$ & -- & $<10$ \\
\hline MV-62B* & -- & $<10$ & -- & $<.5$ & -- & $<10$ \\
\hline
\end{tabular}


Table 10.-Concentrations of dissolved trace elements and hexavalent and total chromium in water from selected wells and springs, eastern Snake River Plain-Continued

\begin{tabular}{|c|c|c|c|c|c|c|}
\hline $\begin{array}{c}\text { Site } \\
\text { identifier }\end{array}$ & $\begin{array}{l}\text { Nickel } \\
\text { NWQL }\end{array}$ & $\begin{array}{l}\text { Nickel } \\
\text { IDHWL }\end{array}$ & $\begin{array}{l}\text { Selenium } \\
\text { NWQL }\end{array}$ & $\begin{array}{l}\text { Selenium } \\
\text { IDHWL }\end{array}$ & $\begin{array}{c}\text { Silver } \\
\text { NWQL }\end{array}$ & $\begin{array}{l}\text { Silver } \\
\text { IDHWL }\end{array}$ \\
\hline MV-03 & $<10$ & $<10$ & $<1$ & $<5$ & $<1$ & $<1$ \\
\hline MV-05 & $<10$ & $<10$ & 1 & $<5$ & 1 & $<1$ \\
\hline MV-06 & $<10$ & $<10$ & $<1$ & $<5$ & $<1$ & $<1$ \\
\hline MV-07 & $<10$ & $<10$ & $<1$ & $<5$ & $<1$ & $<1$ \\
\hline MV-13 & $<10$ & $<10$ & $<1$ & $<5$ & $<1$ & $<1$ \\
\hline MV-17 & $<10$ & $<10$ & $<1$ & $<5$ & $<1$ & $<1$ \\
\hline MV-20 & $<10$ & $<10$ & $<1$ & $<5$ & $<1$ & $<1$ \\
\hline MV-27 & $<10$ & $<10$ & $<1$ & $<5$ & $<1$ & $<1$ \\
\hline MV-31 & $<10$ & $<10$ & $<1$ & $<5$ & $<1$ & $<1$ \\
\hline MV-35 & $<10$ & $<10$ & $<1$ & $<5$ & $<1$ & $<1$ \\
\hline MV-36 & $<10$ & $<10$ & $<1$ & $<5$ & 1 & $<1$ \\
\hline MV-38 & $<10$ & $<10$ & $<1$ & $<5$ & $<1$ & $<1$ \\
\hline MV-44* & $<10$ & $<10$ & $<1$ & $<5$ & $<1$ & $<1$ \\
\hline MV-46 & $<10$ & $<10$ & $<1$ & $<5$ & $<1$ & $<1$ \\
\hline MV-50 & $<10$ & $<10$ & 1 & $<5$ & 1 & $<1$ \\
\hline MV-53 & $<10$ & $<10$ & $<1$ & $<5$ & $<1$ & $<1$ \\
\hline MV-55 & $<10$ & $<10$ & $<1$ & $<5$ & $<1$ & $<1$ \\
\hline MV-57 & $<10$ & $<10$ & 1 & $<5$ & 1 & $<1$ \\
\hline MV-58 & $<10$ & $<10$ & $<1$ & $<5$ & $<1$ & $<1$ \\
\hline MV-60* & $<10$ & $<10$ & $<1$ & $<5$ & $<1$ & $<1$ \\
\hline MV-62A* & - & $<10$ & -- & $<5$ & -- & $<1$ \\
\hline MV-62B* & -- & $<10$ & -- & $<5$ & -- & $<1$ \\
\hline
\end{tabular}


Table 10. Concentrations of dissolved trace elements and hexavalent and total chromium in water from selected wells and springs, eastern Snake River Plain-Continued

\begin{tabular}{|c|c|c|c|c|c|c|}
\hline $\begin{array}{c}\text { Site } \\
\text { identifier }\end{array}$ & $\begin{array}{l}\text { Strontium } \\
\text { NWQL }\end{array}$ & $\begin{array}{l}\text { Strontium } \\
\text { IDHWL }\end{array}$ & $\begin{array}{l}\text { Vanadium } \\
\text { NWQL }\end{array}$ & $\begin{array}{l}\text { Vanadium } \\
\text { IDHWL }\end{array}$ & $\begin{array}{c}\text { Zinc } \\
\text { NWQL }\end{array}$ & $\begin{array}{l}\text { Zinc } \\
\text { IDHWL }\end{array}$ \\
\hline MV-03 & 190 & 200 & 7 & 12 & $<3$ & $<2$ \\
\hline MV-05 & 300 & 300 & 9 & 13 & 22 & 20 \\
\hline MV-06 & 380 & 400 & $<6$ & $<10$ & 8 & $<2$ \\
\hline MV-07 & 190 & 170 & 7 & 12 & 6 & $<2$ \\
\hline MV-13 & 270 & 260 & 8 & 10 & 4 & $<2$ \\
\hline MV-17 & 200 & 190 & 9 & 13 & 8 & $<2$ \\
\hline MV-20 & 190 & 180 & 10 & 15 & 6 & 3 \\
\hline MV-27 & 340 & 330 & 7 & 10 & 5 & 2 \\
\hline MV-31 & 310 & 310 & 7 & 10 & 7 & $<2$ \\
\hline MV-35 & 150 & 150 & 8 & 10 & 3 & $<2$ \\
\hline MV-36 & 210 & 210 & 7 & $<10$ & $<3$ & $<2$ \\
\hline MV-38 & 170 & 160 & 6 & 11 & $<3$ & $<2$ \\
\hline MV-44* & 150 & 160 & 9 & 10 & $<3$ & $<2$ \\
\hline MV-46 & 150 & 170 & 9 & 11 & $<3$ & $<2$ \\
\hline MV-50 & 350 & 330 & 8 & $<10$ & 9 & 10 \\
\hline MV-53 & 410 & 450 & 7 & $<10$ & 43 & 40 \\
\hline MV-55 & 200 & 180 & 9 & 15 & $<3$ & $<2$ \\
\hline MV-57 & 130 & 150 & 9 & 10 & 22 & 24 \\
\hline MV-58 & 110 & 130 & 11 & 12 & 57 & 38 \\
\hline MV-60* & 210 & 200 & 7 & $<10$ & 30 & $<2$ \\
\hline MV-62A* & -- & 1.7 & -- & $<10$ & -- & $<2$ \\
\hline MV-62B* & -- & $<1$ & -- & $<10$ & -- & $<2$ \\
\hline
\end{tabular}


Barium.-Concentrations of barium in all samples analyzed by the NWQL were greater than the reporting level and ranged from 5 to $91 \mu \mathrm{g} / \mathrm{L}$. Concentrations of barium in four samples analyzed by the IDHWL were equal to the reporting level of $100 \mu \mathrm{g} / \mathrm{L}$. The maximum contaminant level is $1,000 \mu \mathrm{g} / \mathrm{L}$.

Beryllium.-Concentrations of beryllium in four samples analyzed by the NWQL were greater than the reporting level and ranged from 0.8 to $1.1 \mu \mathrm{g} / \mathrm{L}$. Concentrations of beryllium in all samples analyzed by the IDHWL were less than the reporting level of $5 \mu \mathrm{g} / \mathrm{L}$. The proposed maximum contaminant level is $1 \mu \mathrm{g} / \mathrm{L}$.

Cadmium.-Concentrations of cadmium in three samples analyzed by the NWQL were equal to or greater than the reporting level and ranged from 1 to $2 \mu \mathrm{g} / \mathrm{L}$. Concentrations of cadmium in all samples analyzed by the IDHWL were less than the reporting level of $1 \mu \mathrm{g} / \mathrm{L}$. The maximum contaminant level is $10 \mu \mathrm{g} / \mathrm{L}$.

Chromium.-Chromium analyses included dissolved, hexavalent and total chromium. All the samples analyzed by the NWQL had dissolved chromium concentrations less than the reporting level of $5 \mu \mathrm{g} / \mathrm{L}$. Dissolved chromium concentrations in 14 samples analyzed by the IDHWL equaled or exceeded the reporting level and ranged from 2.0 to $4.1 \mu \mathrm{g} / \mathrm{L}$. Hexavalent chromium concentrations in six samples analyzed by the NWQL equaled or exceeded the reporting level and ranged from 1 to $4 \mu \mathrm{g} / \mathrm{L}$. Concentrations of total chromium in 13 samples analyzed by the NWQL equaled or exceeded the reporting level and ranged from 1 to $5 \mu \mathrm{g} / \mathrm{L}$; the maximum contaminant level is $50 \mu \mathrm{g} / \mathrm{L}$.

Cobalt.-Concentrations of cobalt in all the samples analyzed by the NWQL were less than the reporting level of $3 \mu \mathrm{g} / \mathrm{L}$. Concentrations of cobalt in all the samples analyzed by the IDHWL were less than the reporting level of $10 \mu \mathrm{g} / \mathrm{L}$.

Copper--Concentrations of copper in all the samples analyzed by the NWQL and the IDHWL were less than the reporting levels of $10 \mu \mathrm{g} / \mathrm{L}$. The proposed maximum contaminant level is $1,300 \mu \mathrm{g} / \mathrm{L}$.
Iron.-Concentrations of iron in seven samples analyzed by the NWQL exceeded the reporting level and ranged from 4 to $18 \mu \mathrm{g} / \mathrm{L}$. Concentrations of iron in all the samples analyzed by the IDHWL were less than the reporting level of $10 \mu \mathrm{g} / \mathrm{L}$. The secondary maximum contaminant level is $300 \mu \mathrm{g} / \mathrm{L}$.

Lead-Concentrations of lead in all the samples analyzed by the NWQL were less than the reporting level of $1 \mu \mathrm{g} / \mathrm{L}$. Concentrations of lead in all samples analyzed by the IDHWL were less than the reporting level of $5 \mu \mathrm{g} / \mathrm{L}$. The maximum contaminant level is $50 \mu \mathrm{g} / \mathrm{L}$.

Lithium.-Concentrations of lithium in all the samples analyzed by the NWQL exceeded the reporting level and ranged from 5 to $53 \mu \mathrm{g} / \mathrm{L}$. Concentrations of lithium in 18 samples analyzed by the IDHWL equaled or exceeded the reporting level and ranged from 10 to $60 \mu \mathrm{g} / \mathrm{L}$.

Manganese.-Concentrations of manganese in samples from MV-57 and MV-58 analyzed by the NWQL exceeded the reporting level with 3 and $5 \mu \mathrm{g} / \mathrm{L}$, respectively. Concentrations of manganese in all the samples analyzed by the IDHWL were less than the reporting level of $10 \mu \mathrm{g} / \mathrm{L}$. The secondary maximum contaminant level is $50 \mu \mathrm{g} / \mathrm{L}$.

Mercury - All the samples analyzed by the NWQL had mercury concentrations less than the reporting level of $0.1 \mu \mathrm{g} / \mathrm{L}$. All the samples analyzed by the IDHWL had mercury concentrations less than the reporting level of $0.5 \mu \mathrm{g} / \mathrm{L}$. The maximum contaminant level is $2 \mu \mathrm{g} / \mathrm{L}$.

Molybdenum.-All but one sample analyzed by the NWQL had molybdenum concentrations less than the reporting level of $10 \mu \mathrm{g} / \mathrm{L}$. MV-46 had a concentration of $10 \mu \mathrm{g} / \mathrm{L}$. All the samples analyzed by the IDHWL had molybdenum concentrations less than the reporting level of $10 \mu \mathrm{g} / \mathrm{L}$.

Nickel.-All the samples analyzed by the NWQL and the IDHWL had nickel concentrations less than the reporting levels of $10 \mu \mathrm{g} / \mathrm{L}$. The proposed maximum contaminant level is $100 \mu \mathrm{g} / \mathrm{L}$. 
Selenium -Concentrations of selenium in three samples analyzed by the NWQL were equal to the reporting level of $1 \mu \mathrm{g} / \mathrm{L}$. All the samples analyzed by the IDHWL had selenium concentrations less than the reporting level of $5 \mu \mathrm{g} / \mathrm{L}$. The maximum contaminant level is $10 \mu \mathrm{g} / \mathrm{L}$.

Silver.-Concentrations of silver in four samples analyzed by the NWQL were equal to the reporting level of $1 \mu \mathrm{g} / \mathrm{L}$. All the samples analyzed by the IDHWL had silver concentrations less than the reporting level of $1 \mu \mathrm{g} / \mathrm{L}$. The maximum contaminant level is $50 \mu \mathrm{g} / \mathrm{L}$.

Strontium.-Concentrations of strontium in all samples analyzed by the NWQL exceeded the reporting level and ranged from 110 to $410 \mu \mathrm{g} / \mathrm{L}$. Strontium concentrations in all samples analyzed by the IDHWL exceeded the reporting level and ranged from 130 to $450 \mu \mathrm{g} / \mathrm{L}$.

Vanadium.-Concentrations of vanadium in 19 samples analyzed by the NWQL equaled or exceeded the reporting level and ranged from 6 to $11 \mu \mathrm{g} / \mathrm{L}$. Concentrations of vanadium in 15 samples analyzed by the IDHWL equaled or exceeded the reporting level and ranged from 10 to $15 \mu \mathrm{g} / \mathrm{L}$.

Zinc. - Concentrations of zinc in 14 samples analyzed by the NWQL equaled or exceeded the reporting level and ranged from 3 to $57 \mu \mathrm{g} / \mathrm{L}$. Concentrations of zinc in seven samples analyzed by the IDHWL equaled or exceeded the reporting level and ranged from 2 to $40 \mu \mathrm{g} / \mathrm{L}$.

\section{Common lons}

Water samples were analyzed by the NWQL for dissolved common ions including bromide, calcium, chloride, fluoride, magnesium, potassium, silica, sodium, and sulfate. Water samples were analyzed by the IDHWL for total calcium, chloride, fluoride, magnesium, potassium, silica, sodium, and sulfate. The maximum contaminant levels or secondary maximum contaminant levels and the reporting levels for these ions are shown on table 11. The concentrations of dissolved common ions are shown on table 12 . The concentrations of total common ions are shown on table 13.
Bromide - Concentrations of dissolved bromide in all samples analyzed by the NWQL exceeded the reporting level and ranged from 0.02 to $0.17 \mathrm{mg} / \mathrm{L}$.

Calcium.-Dissolved calcium concentrations in all samples analyzed by the NWQL exceeded the reporting level and ranged from 23 to $70 \mathrm{mg} / \mathrm{L}$. Total calcium concentrations in all samples analyzed by the IDHWL exceeded the reporting level and ranged from 24 to $73 \mathrm{mg} / \mathrm{L}$.

Chloride.-Dissolved chloride concentrations in all samples analyzed by the NWQL exceeded the reporting level and ranged from 5.5 to $77 \mathrm{mg} / \mathrm{L}$. Total chloride concentrations in all samples analyzed by the IDHWL exceeded the reporting level and ranged from 5.5 to $73 \mathrm{mg} / \mathrm{L}$. The secondary maximum contaminant level is $250 \mathrm{mg} / \mathrm{L}$.

Fluoride.-Concentrations of dissolved fluoride in all samples analyzed by the NWQL exceeded the reporting level and ranged from 0.1 to $0.7 \mathrm{mg} / \mathrm{L}$. Concentrations of total fluoride in all samples analyzed by the IDHWL exceeded the reporting level and ranged from 0.24 to $0.74 \mathrm{mg} / \mathrm{L}$. The maximum contaminant level is $4 \mathrm{mg} / \mathrm{L}$.

Magnesium.-Dissolved magnesium concentrations in all samples analyzed by the NWQL exceeded the reporting level and ranged from 11 to $26 \mathrm{mg} / \mathrm{L}$. Total magnesium concentrations in all samples analyzed by the IDHWL exceeded the reporting level and ranged from 11 to $26.5 \mathrm{mg} / \mathrm{L}$.

Potassium.-Concentrations of dissolved potassium in all samples analyzed by the NWQL exceeded the reporting level and ranged from 2.4 to $6.9 \mathrm{mg} / \mathrm{L}$. Concentrations of total potassium in all samples analyzed by the IDHWL exceeded the reporting level and ranged from 2.6 to $7.3 \mathrm{mg} / \mathrm{L}$.

Silica.-Dissolved silica concentrations in all samples analyzed by the NWQL were greater than the reporting level and ranged from 26 to 42 $\mathrm{mg} / \mathrm{L}$. Total silica concentrations in all samples analyzed by the IDHWL were greater than the reporting level and ranged from 26 to $41 \mathrm{mg} / \mathrm{L}$. 
Table 11.-Maximum contaminant levels and reporting levels of selected common ions in drinking water

[The maximum contaminant levels are for total measurements and were established pursuant to the recommendations of the U.S. Environmental Protection Agency (1989, p. 547) for community water systems and are for comparison purposes only. Secondary maximum contaminant levels - in brackets - are from U.S. Environmental Protection Agency (1989, 1990a). Reporting levels for the U.S. Geological Survey National Water Quality Laboratory (NWQL) are from Pritt and Jones (1989). Reporting levels for the Idaho Department of Health and Welfare Laboratory (IDHWL) are from J. Dodds, (written commun., 1991). Units are in milligrams per liter (mg/L). Symbols: --, maximum contaminant level has not been established for the chemical constituent; **, analysis not requested]

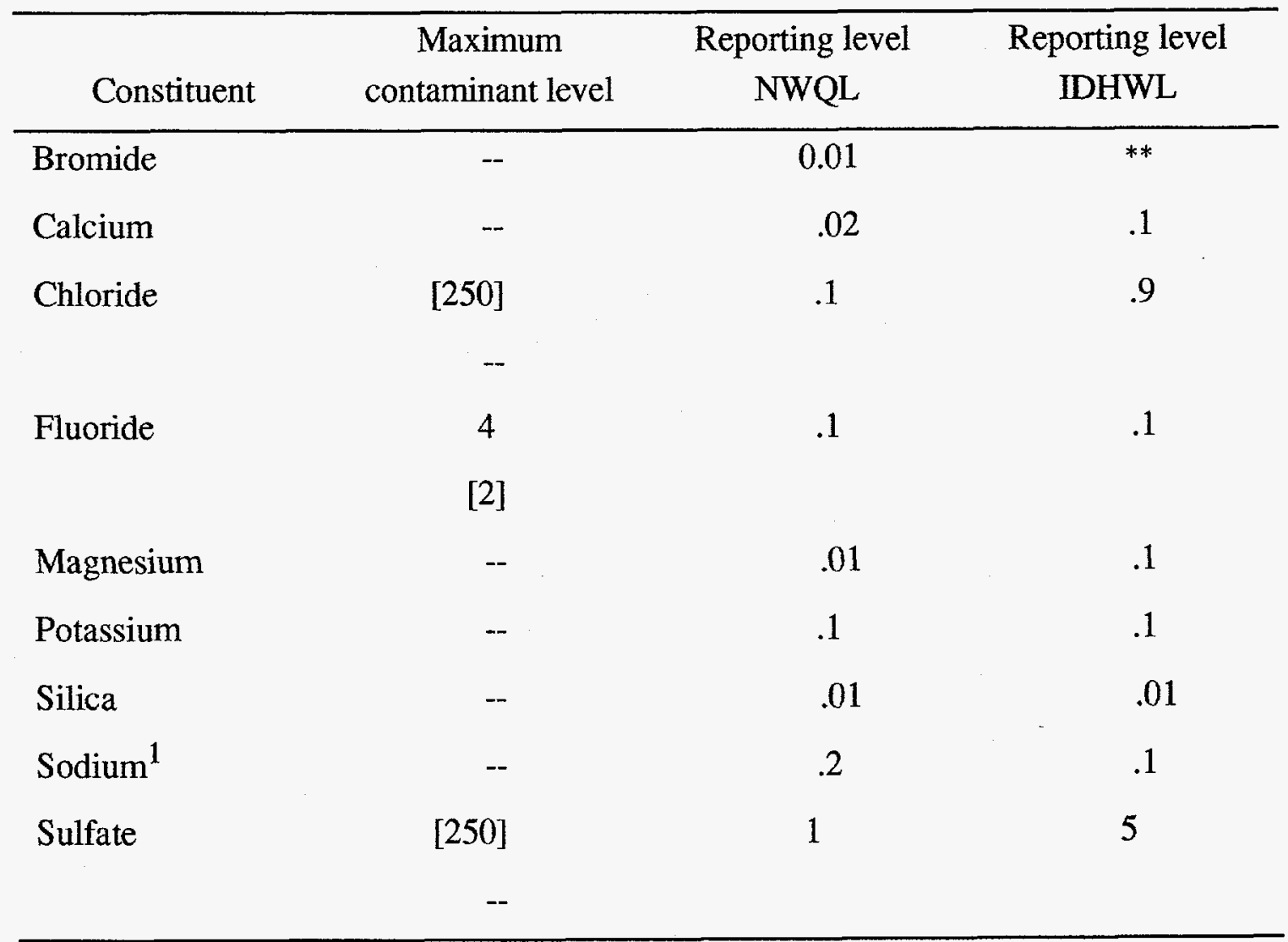

\footnotetext{
${ }^{1}$ Idaho Department of Health and Welfare (1989) recommends an optimum concentration of $20 \mathrm{mg} / \mathrm{L}$.
} 
Table 12.-Concentrations of dissolved common ions in water from selected wells and springs, eastern Snake River Plain

[See figure 2 for location of sites. Analyses were performed by the U.S. Geological Survey National Water Quality Laboratory. Analytical results in milligrams per liter (mg/L). Symbol: *, quality assurance sample (MV-44 is a replicate of MV-46, MV-60 is a replicate of MV-36)]

\begin{tabular}{|c|c|c|c|c|c|c|c|c|c|}
\hline $\begin{array}{c}\text { Site } \\
\text { identifier }\end{array}$ & Bromide & Calcium & Chloride & Fluoride & Magnesium & Potassium & Silica & Sodium & Sulfate \\
\hline MV-03 & 0.06 & 37 & 29 & 0.7 & 15 & 3 & 32 & 22 & 34 \\
\hline MV-05 & .13 & 51 & 64 & .6 & 22 & 5.3 & 32 & 45 & 73 \\
\hline MV-06 & .05 & 70 & 32 & .1 & 20 & 5.2 & 30 & 25 & 47 \\
\hline MV-07 & .04 & 35 & 15 & .6 & 14 & 3.2 & 32 & 16 & 32 \\
\hline MV-13 & .08 & 58 & 43 & .3 & 19 & 6.5 & 42 & 41 & 59 \\
\hline MV-17 & .05 & 39 & 24 & .6 & 16 & 3.5 & 34 & 20 & 37 \\
\hline MV-20 & .04 & 37 & 18 & .5 & 18 & 3.6 & 34 & 22 & 34 \\
\hline MV-27 & .16 & 67 & 62 & .5 & 23 & 5.3 & 34 & 34 & 68 \\
\hline MV-31 & .13 & 58 & 54 & .5 & 22 & 4.6 & 33 & 30 & 61 \\
\hline MV-35 & .02 & 26 & 9.2 & .4 & 13 & 3.1 & 31 & 14 & 22 \\
\hline MV-36 & .03 & 51 & 12 & .3 & 16 & 3.1 & 29 & 17 & 26 \\
\hline MV-38 & .03 & 39 & 11 & .3 & 14 & 3.2 & 30 & 14 & 23 \\
\hline MV-44* & .02 & 28 & 9.3 & .4 & 14 & 3.3 & 32 & 14 & 21 \\
\hline$M V-46$ & .02 & 27 & 9.4 & .4 & 13 & 3.3 & 32 & 14 & 22 \\
\hline MV-50 & .16 & 66 & 62 & .3 & 23 & 6.1 & 32 & 41 & 76 \\
\hline MV-53 & .17 & 64 & 77 & .4 & 26 & 6.9 & 35 & 58 & 75 \\
\hline MV-55 & .05 & 37 & 28 & .6 & 17 & 3.7 & 33 & 20 & 40 \\
\hline MV-57 & .02 & 23 & 6.2 & .4 & 11 & 2.4 & 28 & 12 & 16 \\
\hline MV-58 & .02 & 25 & 5.5 & .4 & 12 & 3 & 26 & 16 & 9.4 \\
\hline MV-60* & .04 & 51 & 12 & .3 & 17 & 3.1 & 29 & 17 & 26 \\
\hline
\end{tabular}


Table 13.-Concentrations of total common ions in water from selected wells and springs, eastern Snake River Plain

[See figure 2 for location of sites. Analyses were performed by the Idaho Department of Health and Welfare Laboratory. Analytical results in milligrams per liter (mg/L). Symbol: *, quality assurance sample (MV-44 is a replicate of MV-46, MV-60 is a replicate of MV-36)]

\begin{tabular}{|c|c|c|c|c|c|c|c|c|}
\hline $\begin{array}{c}\text { Site } \\
\text { identifier }\end{array}$ & Calcium & Chloride & Fluoride & Magnesium & Potassium & Silica & Sodium & Sulfate \\
\hline MV-03 & 39 & 28 & 0.74 & 15 & 3.5 & 30.7 & 25 & 35 \\
\hline MV-05 & 52 & 56 & .66 & 23 & 5.3 & 30.9 & 47 & 72 \\
\hline MV-06 & 73 & 30 & .24 & 20.5 & 5.7 & 28.8 & 27 & 46 \\
\hline MV-07 & 33 & 14 & .56 & 13.5 & 3.4 & 29.9 & 18 & 31 \\
\hline MV-13 & 52 & 38 & .3 & 19.5 & 6.5 & 41 & 44 & 57 \\
\hline MV-17 & 37 & 21 & .47 & 16.5 & 3.7 & 30.7 & 22 & 36 \\
\hline MV-20 & 36 & 17 & .50 & 18 & 3.9 & 32.4 & 24 & 33 \\
\hline MV-27 & 64 & 56 & .40 & 24 & 5.3 & 31.6 & 37 & 69 \\
\hline MV-31 & 57 & 50 & .5 & 23 & 4.8 & 33 & 32 & 58 \\
\hline MV-35 & 25 & 9 & .4 & 13 & 3.3 & 30 & 15 & 19 \\
\hline MV-36 & 54 & 10 & .29 & 17 & 3.4 & 28.3 & 18 & 23 \\
\hline MV-38 & 41 & 10 & .34 & 14 & 3.2 & 28.8 & 18 & 20 \\
\hline $\mathrm{MV}-44^{*}$ & 27 & 9 & .4 & 14.5 & 3.4 & 31 & 16 & 20 \\
\hline$M V-46$ & 27 & 9 & .4 & 14 & 3.3 & 31 & 15 & 19 \\
\hline MV-50 & 70 & 62 & .4 & 25 & 5.3 & 32.7 & 44 & 82 \\
\hline MV-53 & 68 & 73 & .48 & 26.5 & 7.3 & 33.7 & 62 & 82 \\
\hline MV-55 & 38 & 32 & .64 & 17 & 3.8 & 31.2 & 22 & 35 \\
\hline MV-57 & 24 & 6.7 & .4 & 11 & 2.6 & 29 & 12 & 15 \\
\hline MV-58 & 25 & 5.5 & .4 & 12 & 3.0 & 26 & 16 & 11 \\
\hline MV-60* & 54 & 28 & .33 & 17 & 3.4 & 28.4 & 19 & 22 \\
\hline
\end{tabular}


Sodium.-Concentrations of dissolved sodium in all samples analyzed by the NWQL were greater than the reporting level and ranged from 12 to $58 \mathrm{mg} / \mathrm{L}$. Concentrations of total sodium in all samples analyzed by the IDHWL were greater than the reporting level and ranged from 12 to $62 \mathrm{mg} / \mathrm{L}$. The IDHW (1989) recommends an optimum level of $20 \mathrm{mg} / \mathrm{L}$ of sodium for public drinking-water supplies.

Sulfate-Concentrations of dissolved sulfate in all samples analyzed by the NWQL exceeded the reporting level and ranged from 9.4 to $76 \mathrm{mg} / \mathrm{L}$. Concentrations of total sulfate in all samples analyzed by the IDHWL were greater than the reporting level and ranged from 11 to $82 \mathrm{mg} / \mathrm{L}$. The secondary maximum contaminant level is $250 \mathrm{mg} / \mathrm{L}$.

\section{Nutrients and Cyanide}

Water samples were analyzed by the NWQL for dissolved ammonia (as nitrogen), nitrite (as nitrogen), nitrite plus nitrate (as nitrogen), orthophosphate (as phosphorus), and cyanide. The maximum contaminant levels proposed by the U.S. Environmental Protection Agency (1989 and $1990 \mathrm{~b}$ ) and the reporting levels for nitrite, nitrite plus nitrate, and cyanide are shown on table 14. A maximum contaminant level has not been established or proposed for ammonia or orthophosphate.

Concentrations of nutrients and cyanide are shown on table 15. Concentrations of ammonia in 11 samples equaled or exceeded the reporting level and ranged from 0.01 to $0.04 \mathrm{mg} / \mathrm{L}$. Concentrations of nitrite in one sample (MV-13) equaled the reporting level of $0.01 \mathrm{mg} / \mathrm{L}$. Concentrations of nitrite plus nitrate in all samples exceeded the reporting level and ranged from 0.41 to $3.8 \mathrm{mg} / \mathrm{L}$; the maximum contaminant level is $10 \mathrm{mg} / \mathrm{L}$ (table 15 ). Concentrations of orthophosphate as phosphorus in 17 samples equaled or exceeded the reporting level and ranged from 0.01 to $0.03 \mathrm{mg} / \mathrm{L}$. Concentrations of cyanide in all samples were less than the reporting level of $0.01 \mathrm{mg} / \mathrm{L}$.

\section{ORGANIC COMPOUNDS}

Water samples were analyzed by the NWQL for selected organic compounds. These compounds included dissolved organic carbon, surfactants, purgeable organic compounds, insecticides, polychlorinated compounds, and herbicides. Reporting levels established for these constituents (Pritt and Jones, 1989) are not to be confused with reporting levels and analytical method detection limits for selected radionuclides.

\section{Dissolved Organic Carbon}

Water samples were analyzed for DOC and concentrations are shown on table 15 .

Concentrations of DOC in 17 samples were greater than the reporting level of $0.1 \mathrm{mg} / \mathrm{L}$, and ranged from 0.2 to $1.2 \mathrm{mg} / \mathrm{L}$; no maximum contaminant level has been established or proposed.

\section{Surfactants}

Water samples were analyzed for surfactants (table 15). Concentrations of surfactants in 16 samples equaled or exceeded the reporting level and ranged from 0.01 to $0.05 \mathrm{mg} / \mathrm{L}$; the secondary maximum contaminant level is $0.5 \mathrm{mg} / \mathrm{L}$ (U.S. Environmental Protection Agency, 1989).

\section{Purgeable Organic Compounds}

Samples from all sites were analyzed for 63 purgeable organic compounds. The maximum contaminant levels and reporting levels for these compounds are shown on table 16 . None of the samples had concentrations of purgeable organic compounds greater than the reporting levels.

\section{Insecticides and Polychlorinated Compounds}

Water samples were analyzed for concentrations of 10 carbamate insecticides, 11 organophosphorus insecticides, 15 organochlorine insecticides, gross PCB's, and gross PCN's by the NWQL. The maximum contaminant levels and reporting levels for these compounds are shown on table 17. None of the concentrations of these compounds exceeded their respective reporting levels. The laboratory had low surrogate recovery on two samples (MV-44 and MV-60) analyzed for 
Table 14.-Maximum contaminant levels and reporting levels of selected nutrients, cyanide, dissolved organic carbon, and surfactants in drinking water

[The maximum contaminant levels were established pursuant to the recommendations of the U.S. Environmental Protection Agency $(1989,1990$ a) for community water systems and are included for comparison purposes only. Proposed maximum contaminant levels - in parenthesis - are from U.S. Environmental Protection Agency (1990a). The secondary maximum contaminant level —in brackets - is from U.S. Environmental Protection Agency (1989). Reporting levels are from Pritt and Jones (1989). Units are milligrams per liter (mg/L). Symbol: --, maximum contaminant level has not been established or proposed for that constituent]

\begin{tabular}{lcc}
\hline \multicolumn{1}{c}{ Constituent } & Maximum contaminant level & Reporting level \\
\hline Ammonia (as nitrogen) & -- & 0.01 \\
Nitrite (as nitrogen) & $(1)$ & .01 \\
Nitrite plus nitrate (as nitrogen) & 10 & .10 \\
Orthophosphate (as phosphorus) & -- & .01 \\
Cyanide & $(.2)$ & .01 \\
Dissolved organic carbon & -- & .1 \\
Surfactants & {$[0.5]$} & .01 \\
\hline
\end{tabular}


Table 15. Concentrations of nutrients, cyanide, dissolved organic carbon, and surfactants in water from selected wells and springs, eastern Snake River Plain

[See figure 2 for location of sites. Analyses were performed by the U.S. Geological Survey

National Water Quality Laboratory. Analytical results in milligrams per liter (mg/L). Symbols:

$<$, concentration was less than the respective reporting level. SR, sample ruined; *, quality assurance sample (MV-44 is a replicate of MV-46, MV-60 is a replicate of MV-36, MV-62C is an equipment blank); **, analyses not requested]

\begin{tabular}{|c|c|c|c|c|c|c|c|}
\hline $\begin{array}{c}\text { Site } \\
\text { identifier }\end{array}$ & $\begin{array}{l}\text { Ammonia } \\
\quad \text { (as } \\
\text { nitrogen) }\end{array}$ & $\begin{array}{c}\text { Nitrite } \\
\text { (as nitrogen) }\end{array}$ & $\begin{array}{l}\text { Nitrite plus } \\
\text { nitrate } \\
\text { (as nitrogen) }\end{array}$ & $\begin{array}{l}\text { Orthophosphate } \\
\text { (as phosphorus) }\end{array}$ & Cyanide & $\begin{array}{c}\text { Dissolved } \\
\text { organic } \\
\text { carbon }\end{array}$ & Surfactants \\
\hline MV-03 & $<0.01$ & $<0.01$ & 0.99 & 0.02 & $<0.01$ & 0.8 & 0.03 \\
\hline MV-05 & .03 & $<.01$ & 1.9 & .02 & $<.01$ & 1.1 & .03 \\
\hline MV-06 & $<.01$ & $<.01$ & 3.8 & .02 & $<.01$ & .7 & .04 \\
\hline MV-07 & $<.01$ & $<.01$ & .42 & .02 & $<.01$ & $\mathrm{SR}$ & .01 \\
\hline MV-13 & .04 & .01 & 1.5 & .02 & $<.01$ & .7 & .02 \\
\hline MV-17 & .01 & $<.01$ & 1.8 & .02 & $<.01$ & .9 & .03 \\
\hline MV-20 & $<.01$ & $<.01$ & 1.4 & .02 & $<.01$ & $<.1$ & .02 \\
\hline MV-27 & .03 & $<.01$ & .87 & .03 & $<.01$ & SR & .01 \\
\hline MV-31 & $<.01$ & $<.01$ & 1.4 & .01 & $<.01$ & .6 & .02 \\
\hline MV-35 & $<.01$ & $<.01$ & .52 & $<.01$ & $<.01$ & .3 & $<.01$ \\
\hline MV-36 & .01 & $<.01$ & 1.6 & .03 & $<.01$ & .6 & .02 \\
\hline MV-38 & .02 & $<.01$ & 1.2 & .02 & $<.01$ & .5 & .02 \\
\hline MV-44* & $<.01$ & $<.01$ & .62 & $<.01$ & $<.01$ & .2 & $<.01$ \\
\hline MV-46 & $<.01$ & $<.01$ & .61 & $<.01$ & $<.01$ & .2 & $<.01$ \\
\hline MV-50 & .02 & $<.01$ & 2.1 & .02 & $<.01$ & .8 & .05 \\
\hline MV-53 & $<.01$ & $<.01$ & 3.4 & .01 & $<.01$ & 1.2 & .05 \\
\hline MV-55 & .03 & $<.01$ & 1.1 & .01 & $<.01$ & .4 & .02 \\
\hline MV-57 & .02 & $<.01$ & .41 & .01 & $<.01$ & .2 & $<.01$ \\
\hline MV-58 & .03 & $<.01$ & 1.5 & .03 & $<.01$ & .4 & .01 \\
\hline MV-60* & .01 & $<.01$ & 1.7 & .03 & $<.01$ & .5 & .02 \\
\hline MV-62C* & $* *$ & $* *$ & $* *$ & $* *$ & $* *$ & $<.1$ & $* *$ \\
\hline
\end{tabular}


organophosphorus insecticides; so the data for these two samples should be considered "qualified" and reviewed with caution.

\section{Herbicides}

Concentrations of 12 triazine herbicides and 4 chlorophenoxy-acid herbicides were determined by the NWQL. Maximum contaminant levels and reporting levels for these compounds are shown on table 18. One sample (MV-31) was not analyzed for chlorophenoxy-acid herbicides because it was lost in sample preparation. None of the concentrations of these compounds exceeded their respective reporting levels.

\section{TOTAL AND FECAL COLIFORM BACTERIA}

Water samples were analyzed for total and fecal coliform bacteria by the IDHWL at Twin Falls, Idaho. Results are shown on table 19. Presumptive membrane-filter tests indicated the presence of total coliform bacteria in samples from eight wells and one spring and fecal coliform bacteria in samples from four wells and one spring. The maximum contaminant level for bacteria in public drinking-water supplies is based on the absence of total coliforms (zero colonies per $100 \mathrm{~mL}$ ) (U.S. Environmental Protection Agency, 1990a). Because total coliform bacteria were present in nine samples, the amount of bacteria would exceed the maximum contaminant level if the sites were public drinking water supplies.

\section{SUMMARY}

The USGS and the Idaho Department of Water Resources, in response to a request from the DOE, sampled 18 sites as part of a long-term project to monitor water quality of the Snake River Plain aquifer from the southern boundary of the Idaho National Engineering Laboratory to the Hagerman area. Water samples were collected and analyzed for selected radionuclides, inorganic constituents, organic compounds, and bacteria. The samples were collected from 13 irrigation wells, 1 domestic well, 1 spring, 2 stock wells, and 1 public supply well. Quality assurance samples also were collected and analyzed.

Radon-222 was detected at concentrations exceeding the reporting level in 19 samples, but none exceeded the proposed maximum contaminant level. Concentrations of strontium-90 in all samples were less than the reporting level. Tritium concentrations in 18 samples analyzed by the NWQL were greater than the reporting level, but none exceeded the maximum contaminant level for drinking water. All samples analyzed by ISU had concentrations of tritium less than the reporting level.

Concentrations of dissolved gross alphaparticle radioactivity in all samples exceeded the reporting level; none exceeded the maximum contaminant level. Concentrations of dissolved gross beta-particle radioactivity in all samples exceeded the reporting level. Total gross betaparticle radioactivity in nine samples equaled or exceeded the reporting level. Dissolved total uranium concentrations exceeded the reporting level in all water samples, but none exceeded the proposed maximum contaminant level. Radium226 concentrations in 18 samples exceeded the reporting level; radium-228 concentrations in 5 samples exceeded the reporting level; none exceeded the maximum contaminant levels for radium isotopes. Five radionuclides were identified using gamma spectroscopy. Cesium-137 was identified in all the samples, radium-226 in 7 samples, uranium-235 in 2 samples, uranium-238 in 10 samples, and potassium-40 in 11 samples. Concentrations of radium-226 in five samples, uranium-235 in one sample, uranium-238 in eight samples, and potassium- 40 in eight samples exceeded the reporting level.

All the samples contained one or more dissolved trace elements and common ions in concentrations greater than the reporting levels. None of the concentrations exceeded an established maximum contaminant level.

Concentrations of ammonia (as nitrogen) in water samples from 11 sites equaled or exceeded the reporting level. Concentrations of nitrite (as nitrogen) in one sample equaled the reporting level. Concentrations of nitrite plus nitrate (as 
Table 16.-Maximum contaminant levels and reporting levels of selected purgeable organic compounds in drinking water

[Analyses were performed by the U.S. Geological Survey National Water Quality Laboratory using an analytical method equivalent to U.S. Environmental Protection Agency method 524.2. Proposed maximum contaminant levels-in parenthesis-are from J. Rodin (U.S. Environmental Protection Agency, written commun., 1989) and U.S. Environmental Protection Agency (1990a,b, 1991b). Units are in micrograms per liter $(\mu \mathrm{g} / \mathrm{L})$. Symbols: --, maximum contaminant level has not been established or proposed for that compound; *, total trihalomethanes-which include bromoform, chloroform, chlorodibromomethane, and dichlorobromomethane-in community water systems serving 10,000 or more persons cannot exceed $100 \mu \mathrm{g} / \mathrm{L}$ (U.S. Environmental Protection Agency, 1989, p. 548)]

\begin{tabular}{|c|c|c|c|c|c|}
\hline Compound & 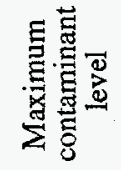 & 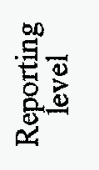 & Compound & 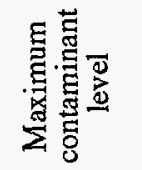 & 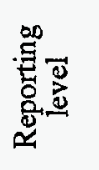 \\
\hline Acrolein & - & 20 & 1,3-Dichloropropane & $\overline{--}$ & .2 \\
\hline Acrylonitrile & -- & 20 & 2,2-Dichloropropane & -- & .2 \\
\hline Benzene & 5.0 & 0.2 & Cis-1,3-Dichloropropene & - & .2 \\
\hline Bromobenzene & -- & .2 & Trans-1,3-Dichloropropene & -- & .2 \\
\hline Bromochloromethane & - & .2 & 1,3-Dichloropropene & -- & .2 \\
\hline Bromoform & * & .2 & Ethylbenzene & $(700)$ & .2 \\
\hline N-Butylbenzene & -- & .2 & Hexachlorobutadiene & -- & .2 \\
\hline Sec-butylbenzene & - & .2 & Isopropylbenzene & -- & .2 \\
\hline Tert-butylbenzene & -- & .2 & P-Isopropyltoluene & -- & .2 \\
\hline Carbon tetrachloride & 5.0 & .2 & Methylbromide & -- & .2 \\
\hline Chlorobenzene & $(100)$ & .2 & Methylene chloride & -- & .2 \\
\hline Chlorodibromomethane & * & .2 & Methyltertbutylether & -- & 1.0 \\
\hline Chloroethane & -- & .2 & Naphthalene & -- & .2 \\
\hline 2-Chloroethyl vinyl ether & -- & 1.0 & N-propylbenzene & -- & .2 \\
\hline Chloroform & * & .2 & Styrene & $(100)$ & .2 \\
\hline Chloromethane & - & .2 & 1,1,1,2-Tetrachloroethane & -- & .2 \\
\hline 1,2-Chlorotoluene & - & .2 & 1,1,2,2-Tetrachloroethane & -- & .2 \\
\hline 1,4-Chlorotoluene & -- & .2 & Tetrachloroethylene & $(5.0)$ & .2 \\
\hline Dibromochloropropane & 0.2 & 1.0 & Toluene & $(2,000)$ & .2 \\
\hline 1,2-Dibromoethane & -- & .2 & 1,2,3-Trichlorobenzene & - & .2 \\
\hline Dibromomethane & - & .2 & 1,2,4-Trichlorobenzene & (9) & .2 \\
\hline 1,2-Dichlorobenzene & $(600)$ & .2 & 1,1,1-Trichloroethane & 200 & .2 \\
\hline 1,3-Dichlorobenzene & -- & .2 & 1,1,2-Trichloroethane & (5) & .2 \\
\hline 1,4-Dichlorobenzene & 75 & .2 & Trichloroethylene & 5.0 & .2 \\
\hline Dichlorobromomethane & * & .2 & Trichlorofluoromethane & - & .2 \\
\hline Dichlorodifluoromethane & -- & .2 & 1,2,3-Trichloropropane & -- & .2 \\
\hline 1,1-Dichloroethane & -- & .2 & Trichlorotrifluoroethane & -- & .5 \\
\hline 1,2-Dichloroethane & 5.0 & .2 & 1,2,4-Trimethylbenzene & -- & .2 \\
\hline Cis-1,2-Dichloroethene & - & .2 & 1,3,5-Trimethylbenzene & -- & .2 \\
\hline 1,1-Dichloroethylene & 7.0 & .2 & Vinyl chloride & 2.0 & .2 \\
\hline 1,2-trans-Dichloroethylene & $(100)$ & .2 & Xylenes, total ortho, meta, and para & $(10,000)$ & .2 \\
\hline 1,2-Dichloropropane & $(5.0)$ & .2 & & & \\
\hline
\end{tabular}


Table 17.-Maximum contaminant levels and reporting levels of selected insecticides and gross polychlorinated compounds in drinking water

[Analyses were performed by the U.S. Geological Survey National Water Quality Laboratory. The maximum contaminant level was established pursuant to the recommendations of the U.S. Environmental Protection Agency (1989, p. 548) for community water systems and are included for comparison purposes only. Proposed maximum contaminant levels - in parentheses-are from U.S. Environmental Protection Agency (1990a, 1991b). Reporting levels are from Pritt and Jones (1989). Units are in micrograms per liter $(\mu \mathrm{g} / \mathrm{L})$. Symbol: --, maximum contaminant level has not been established or proposed for that compound]

Carbamate insecticides: reporting level is $0.5 \mu \mathrm{g} / \mathrm{L}$

\begin{tabular}{lclc}
\multicolumn{1}{c}{ Insecticide } & $\begin{array}{c}\text { Maximum } \\
\text { contaminant level }\end{array}$ & \multicolumn{1}{c}{ Insecticide } & $\begin{array}{c}\text { Maximum } \\
\text { contaminant level }\end{array}$ \\
\hline Aldicarb & $(3)$ & 3-Hydroxycarbofuran & -- \\
Aldicarb sulfone & $(3)$ & Methomyl & -- \\
Aldicarb sulfoxide & $(3)$ & 1-Naphthol & -- \\
Carbaryl (Sevin) & -- & Oxamyl & $(200)$ \\
Carbofuran & $(40)$ & Propham & --
\end{tabular}

Organophosphorus insecticides: reporting level is $0.01 \mu \mathrm{g} / \mathrm{L}$

\begin{tabular}{lclc}
\multicolumn{1}{c}{ Insecticide } & $\begin{array}{c}\text { Maximum } \\
\text { contaminant level }\end{array}$ & \multicolumn{1}{c}{ Insecticide } & $\begin{array}{c}\text { Maximum } \\
\text { contaminant level }\end{array}$ \\
\hline Chlorpyrifos; Dursban & -- & Methyl parathion & -- \\
Diazinon & -- & Methyl trithion & -- \\
Disulfoton & -- & Parathion & -- \\
Ethion & -- & Phorate & -- \\
Fonofos & -- & Trithion & -- \\
Malathion & -- & &
\end{tabular}


Table 17.-Maximum contaminant levels and reporting levels of selected insecticides and gross polychlorinated compounds in drinking water-Continued

Organochlorine insecticides: reporting level is $0.01 \mu \mathrm{g} / \mathrm{L}$ except for chlordane and perthane $(0.1 \mu \mathrm{g} / \mathrm{L})$, and toxaphene $(1.0 \mu \mathrm{g} / \mathrm{L})$

\begin{tabular}{lclc}
\multicolumn{1}{c}{ Insecticide } & $\begin{array}{c}\text { Maximum } \\
\text { contaminant level }\end{array}$ & \multicolumn{1}{c}{ Insecticide } & $\begin{array}{c}\text { Maximum } \\
\text { contaminant level }\end{array}$ \\
\hline Aldrin & -- & Heptachlor & $(0.4)$ \\
Chlordane & $(2)$ & Heptachlor epoxide & $(.2)$ \\
DDD & -- & Lindane & 4 \\
DDE & -- & & $(.2)$ \\
DDT & -- & Methoxychlor & 100 \\
Dieldrin & -- & & $(40)$ \\
Endosulfan & -- & Mirex & - \\
Endrin & -2 & Perthane & - \\
& & Toxaphene & $(5)$
\end{tabular}

Gross polychlorinated compounds: reporting level is $0.1 \mu \mathrm{g} / \mathrm{L}$

Maximum

Compound contaminant level

\begin{tabular}{lc}
\hline Gross polychlorinated biphenyls (PCB's) & $(0.5)$ \\
Gross polychlorinated naphthalenes (PCN's) & -- \\
\hline
\end{tabular}


Table 18.-Maximum contaminant levels and reporting levels of triazines and chlorophenoxyacid herbicides in drinking water

[Analyses were performed by the U.S. Geological Survey National Water Quality Laboratory. The maximum contaminant level was established pursuant to the recommendations of the U.S. Environmental Protection Agency (1989, p. 548) for community water systems and are included for comparison purposes only. Proposed maximum contaminant levels-in parentheses-are from U.S. Environmental Protection Agency (1990a, 1991b). Reporting levels are from Pritt and Jones (1989). Units are in micrograms per liter $(\mu \mathrm{g} / \mathrm{L})$. Symbol: --, maximum contaminant level has not been established or proposed for that compound]

Triazines and other nitrogen-containing herbicides: reporting level is $0.1 \mu \mathrm{g} / \mathrm{L}$

Maximum

Herbicide contaminant level

\begin{tabular}{|c|c|c|c|}
\hline Alachlor & $\overline{(2.0)}$ & Prometon & - \\
\hline Ametryn & -- & Prometryn & -- \\
\hline Atrazine & $(3.0)$ & Propazine & -- \\
\hline Cyanzaine & -- & Simazine & (1) \\
\hline Metolachlor & -- & Simetryn & -- \\
\hline Metribuzin & - & Trifluralin & -- \\
\hline \multicolumn{4}{|c|}{ Chlorophenoxy-acid herbicides: reporting level is $0.01 \mu \mathrm{g} / \mathrm{L}$} \\
\hline Herbicide & $\begin{array}{c}\text { Maximum } \\
\text { contaminant level }\end{array}$ & Herbicide & $\begin{array}{c}\text { Maximum } \\
\text { contaminant level }\end{array}$ \\
\hline $2,4-D$ & $100,(70)$ & Silvex & $10,(50)$ \\
\hline 2,4-DP & -- & $2,4,5-\mathrm{T}$ & -- \\
\hline
\end{tabular}


Table 19.-Presence of total and fecal coliform bacteria in water from selected wells and springs, eastern Snake River Plain

[See figure 2 for location of sites. Analyses performed by the Idaho Department of Health and Welfare Laboratory at Twin Falls, Idaho. Symbols: P, presence of bacteria; A, absence of bacteria; *, quality assurance sample (MV-44 is a replicate of MV-46; MV-60 is a replicate of MV-36); **, analysis not requested]

\begin{tabular}{lcc}
\hline Site identifier & Total coliform bacteria & Fecal coliform bacteria \\
\hline MV-03 & P & A \\
MV-05 & P & A \\
MV-06 & P & A \\
MV-07 & A & A \\
MV-13 & P & P \\
MV-17 & P & P \\
MV-20 & A & A \\
MV-27 & P & P \\
MV-31 & A & A \\
MV-35 & A & A \\
MV-36 & A & A \\
MV-38 & P & P \\
MV-44* & A & A \\
MV-46 & P & P \\
MV-50 & $* *$ & $* *$ \\
MV-53 & P & A \\
MV-55 & A & A \\
MV-57 & A & A \\
MV-58 & A & A \\
MV-60* & A & A \\
\hline
\end{tabular}


nitrogen) in all the water samples exceeded the reporting level. Concentrations of orthophosphate (as phosphorus) in 17 of the water samples equaled or exceeded the reporting level. Concentrations of cyanide in all samples were less than the reporting level. Nutrient concentrations did not exceed established or proposed maximum contaminant levels.

Concentrations of dissolved organic carbon in 17 samples exceeded the reporting level. Concentrations of surfactants in 16 water samples equaled or exceeded the reporting level but did not exceed the secondary maximum contaminant level. No purgeable organic compounds, carbamate insecticides, organophosphorus insecticides, organochlorine insecticides, gross PCB's, gross PCN's, or herbicides were detected at concentrations exceeding their respective reporting levels.

Total coliform bacteria was present in nine samples.

\section{SELECTED REFERENCES}

American Public Health Association and Water Pollution Control Federation, 1985, Standard methods for the examination of water and wastewater: Washington, D.C., American Public Health Association, 1,268 p.

Bartholomay, R.C., Edwards, D.D., and Campbell, L.J., 1992, Radionuclides, inorganic constituents, organic compounds, and bacteria in water from selected wells and springs from the southern boundary of the Idaho National Engineering Laboratory to the Hagerman area, Idaho, 1990: U.S. Geological Survey Open-File Report 92-91 (DOE/ID 22102), 42 p.

-----, 1993, Radionuclides, inorganic constituents, organic compounds, and bacteria in water from selected wells and springs from the southern boundary of the Idaho National Engineering Laboratory to the Hagerman area, Idaho, 1991: U.S. Geological Survey Open-File Report 93-102, (DOE/ID-22108), 42 p.

Claassen, H.C., 1982, Guidelines and techniques for obtaining water samples that accurately represent the water chemistry of an aquifer: U.S. Geological Survey Open-File Report 82-1024, 49 p.
Currie, L.A., 1984, Lower limits of detection-definition and elaboration of a proposed position for radiological effluent and environmental measurements: U.S. Nuclear Regulatory Commission NUREG/CR-4007, $139 \mathrm{p}$.

Fishman, M.J., and Friedman, L.C., eds., 1989, Methods for determination of inorganic substances in water and fluvial sediments: U.S. Geological Survey Techniques of Water-Resources Investigations, book 5, chap. A1, $545 \mathrm{p}$.

Friedman, L.C., and Erdmann, D.E., 1982, Quality assurance practices for the chemical and biological analyses of water and fluvial sediments: U.S. Geological Survey Techniques of WaterResources Investigations, book 5, chap. A6, 181 p.

Garabedian, S.P., 1986, Application of a parameterestimation technique to modeling the regional aquifer underlying the eastern Snake River Plain, Idaho: U.S. Geological Survey Water-Supply Paper 2278, $60 \mathrm{p}$.

Goerlitz, D.F,, and Brown, Eugene, 1972, Methods for analysis of organic substances in water: U.S. Geological Survey Techniques of WaterResources Investigations, book 5, chap. A3, 40 p.

Haglund, D.S., 1972, Uranium-element and geochemistry, in Fairbridge, R.W., ed., The Encyclopedia of geochemistry and environmental sciences: Stroudsberg, Pa., Dowden, Hutchinson, and Ross, $1,321 \mathrm{p}$.

Hardy, M.A., Leahy, P.P., and Alky, W.M., 1989, Well installation and documentation, and ground-water sampling protocols for the pilot National WaterQuality Assessment Program: U.S. Geological Survey Open-File Report 89-396, 36 p.

Idaho Department of Health and Welfare, 1989, Idaho regulations for public drinking water systems: Boise, Rules and Regulations of the Department of Health and Welfare, title 1 , chapter 8 , not paginated.

Jones, B.E., 1987, Quality control manual of the U.S. Geological Survey's National Water Quality Laboratory: U.S. Geological Survey Open-File Report 87-457, $17 \mathrm{p}$.

Kretz, Ralph, 1972, Potassium-element and geochemistry, in Fairbridge, R.W., ed., The Encyclopedia of geochemistry and environmental sciences: Stroudsberg, Pa., Dowden, Hutchinson, and Ross, 1,321 p. 
Mann, L.J., 1986, Hydraulic properties of rock units and chemical quality of water for INEL-1 - a 10,365foot deep test hole drilled at the Idaho National Engineering Laboratory, Idaho: U.S. Geological Survey Water-Resources Investigations Report 86-4020 (DOE/ID-22070), 23 p.

----- 1989, Tritium concentrations in flow from selected springs that discharge to the Snake River, Twin Falls-Hagerman area, Idaho: U.S. Geological Survey Water-Resources Investigations Report 89-456 (DOE/ID-22084), $20 \mathrm{p}$.

Mann, L.J., and Cecil, L.D., 1990, Tritium in ground water at the Idaho National Engineering Laboratory, Idaho: U.S. Geological Survey Water-Resources Investigations Report 90-4090 (DOE/ID-22090), 35 p.

Mann, L.J., and Knobel, L.L., 1990, Radionuclides, metals, and organic compounds in water, eastern part of A\&B Irrigation District, Minidoka County, Idaho: U.S. Geological Survey Open-File Report 90-191 (DOE/ID-22087), 36 p.

Orr, B.R., Cecil, L.D., and Knobel, L.L., 1991, Background concentrations of selected radionuclides, organic compounds, and chemical constituents in ground water in the vicinity of the Idaho National Engineering Laboratory: U.S. Geological Survey Water-Resources Investigations Report 91-4015 (DOE/ID-22094), $52 \mathrm{p}$.

Pittman, J.R., Jensen, R.G., and Fischer, P.R., 1988, Hydrologic conditions at the Idaho National Engineering Laboratory, 1982-1985: U.S. Geological Survey Water-Resources Investigations Report 89-4008 (DOE/ID-22078), $73 \mathrm{p}$.

Pritt, J.W., 1989, Quality assurance of sample containers and preservatives at the U.S. Geological Survey National Water Quality Laboratory, in Pederson, G.L, and Smith, M.M., compilers: U.S. Geological Survey Second National Symposium on Water Quality-Abstracts of the technical sessions, November 12-17, 1989: Orlando, Fla., U.S. Geological Survey Open-File Report 89-409, $111 \mathrm{p}$.

Pritt, J.W., and Jones, B.E., eds., 1989, 1990 National Water Quality Laboratory services catalog: U.S. Geological Survey Open-File Report 89-386, parts $1-5$.
Stevens, H.H., Jr., Ficke, J.F., and Smoot, G.F., 1975, Water temperature--influential factors, field measurement, and data presentation: U.S. Geological Survey Techniques of WaterResources Investigations, book 5, chap. D1, 65 p.

Thatcher, L.L., Janzer, V.J., and Edwards, K.W., 1977, Methods for determination of radioactive substances in water and fluvial sediments: U.S. Geological Survey Techniques of WaterResources Investigations, book 5, chap. A5, 95 p.

U.S. Environmental Protection Agency, 1987, Annual report, fiscal year 1986--methods validation report (radiation): U.S. Environmental Protection Agency Report No. EPA/600/x-87/128, 55 p.

---- 1989, Protection of environment, Code of Federal Regulations 40: Office of the Federal Register, National Archives and Records Administration, parts 100 to $149,948 \mathrm{p}$.

--- 1990a, Fact sheet, Drinking water regulations under the Safe Drinking Water Act: U.S. Environmental Protection Agency Office of Drinking Water, $43 \mathrm{p}$.

---- 1990b, Fact sheet, proposed national primary drinking water regulations for 24 contaminants: U.S. Environmental Protection Agency Office of Drinking Water, $14 \mathrm{p}$.

-.-- 1991a, National primary drinking water regulations; radionuclides; proposed rule: Federal Register, v. 56, no. 138, p. 33,050-33,127.

---- 1991b, Phase II fact sheet, national primary drinking water regulations for 38 inorganic and synthetic organic chemicals: U.S. Environmental Protection Agency Office of Drinking Water, 8 p.

Wegner, S.J., 1989, Selected water quality assurance data for water samples collected by the U.S. Geological Survey, Idaho National Engineering Laboratory, Idaho, 1980 to 1988: U.S. Geological Survey Water-Resources Investigations Report 89-4168 (DOE/ID-22085), $91 \mathrm{p}$.

Wegner, S.J., and Campbell, L.J., 1991, Radionuclides, chemical constituents, and organic compounds in water from designated wells and springs from the southern boundary of the Idaho National Engineering Laboratory to the Hagerman area, Idaho, 1989: U.S. Geological Survey Open-File Report 91-232 (DOE/ID-22098), 49 p. 
Wershaw, R.L., Fishman, M.J., Grabbe, R.R., and Lowe, L.E., 1987, Methods for the determination of organic substances in water and fluvial sediments: U.S. Geological Survey Techniques of Water-Resources Investigations, book 5, chap. A3, $80 \mathrm{p}$.

Whitehead, R.L., 1986, Geohydrologic framework of the Snake River Plain, Idaho and eastern Oregon: U.S. Geological Survey Hydrologic Investigations Atlas HA-681, 3 sheets, scale 1:1,000,000.

Wood, W.W., 1981, Guidelines for collection and field analysis of ground-water samples for selected unstable constituents: U.S. Geological Survey Techniques of Water-Resources Investigations, book 1, chap. D2, 24 p. 